\title{
『徳川実紀』にみる江戸時代前中期の 道路行政政策に関する研究
}

\author{
西山 孝樹 1 藤田 龍之 2 - 天野 光一 3 \\ 1正会員 日本大学助教 理工学部まちづくり工学科（†101-8308 東京都千代田区神田駿河台1-8-14） \\ E-mail: nishiyama.takaki@nihon-u.ac.jp \\ 2正会員 イムノサイエンス株式会社（†963-8852 福島県郡山市台新1-10-11） \\ E-mail: info@imuno.co.jp \\ 3フェロー会員 日本大学教授 理工学部まちづくり工学科（干101-8308 東京都千代田区神田駿河台1-8-14） \\ E-mail: amano.kouichi@nihon-u.ac.jp
}

\begin{abstract}
わが国の近世以降に実施された社会基盤整備は，現代へ繋がる萌芽であったとされる。しかし，江戸幕 府下に実施された先の整備は，一次史料から網羅的に明らかになっていないのが現状である。

そこで本研究では，幕府が編纂した公式記録『徳川実紀』を用いて，江戸時代前中期に実施された道路 行政政策に着目した。その結果，「道路」に関する記述は，維持管理等を定めた「規則の制定」に関する 記述が最も多かった。一方, 「道路」の新規造成や補修等, 「道路施工」に関寸るものは非常に少ない状 況であった。研究対象とした時代は，「道路」の維持管理は行われたものの, 幕府直轄による道路造成は 積極的に行われていなかった。幕藩体制を維持するために江戸へ攻め込まれることを防ぐ必要もあり，土 木工事を抑えていたと推察される状況にあったことを示した。
\end{abstract}

Key Words : Tokugawa Jikki, Edo Shogunate, road administration, blank time period, Bon-do

\section{1. はじめに}

\section{(1) 研究の背景}

筆者らは，わが国における古代から中世にかけて行わ れてきた社会基盤整備の実態について整理してきた（図 -1） 1) 2). 3 世紀末から 6 世紀には，民衆が参加した祭政 一致の社会基盤整備ともいえる古墳が畿内を中心に全国 各地で造営された，例えば，大阪府堺市に現存する大仙 陵古墳（現，仁徳天皇陵）に代表される陵墓は，世界的 にみても巨大構造物であった。 しかしながら，大化 2

（646）年に薄葬令が発布されたことも相まって，7 世 紀代には古墳時代が終焉を迎えていった.

7 世紀後半からは, 発掘等からも明らかになっている 五畿七道と呼ばれた古代道路が全国的に整備された ${ }^{3)}$. 律令国家が 8 世紀頃に成立するのと同時期に土木事業も 最盛期を迎えた。しかし，その律令による中央集権的な 国家体制，およびその機能は次第に衰退していった ${ }^{4)}$.

9 世紀以降では，平安時代末期の承安 3（1173）年, 平清盛による大輪田泊が修築された程度であった，その ことから，図-1 に示した平安時代の 9 世紀（801 年）か ら 11 世紀（1100 年）までは, 社会基盤整備事業がほと
んど行われていない「土木事業の空白期」であったとみ られる. 背景には，土そのものに触ると崇りを受けると いう陰陽道に端を発する「犯土」思想が存在していた ${ }^{2}$. 3 尺（約 $90.9 \mathrm{~cm} ）$ よりも媣く地面を掘削できず，社会基 盤整備のなかで土工事は全くといっていいほど実施され なかった。

続く中世においても，図-1に示した先の思想が影響し て鎌倉時代を中心に「土木事業の停滞期」であったと考 えられる. 室町時代には，石積みや掘割の造成などはみ られたものの, それらは築城に付随した事業であった.

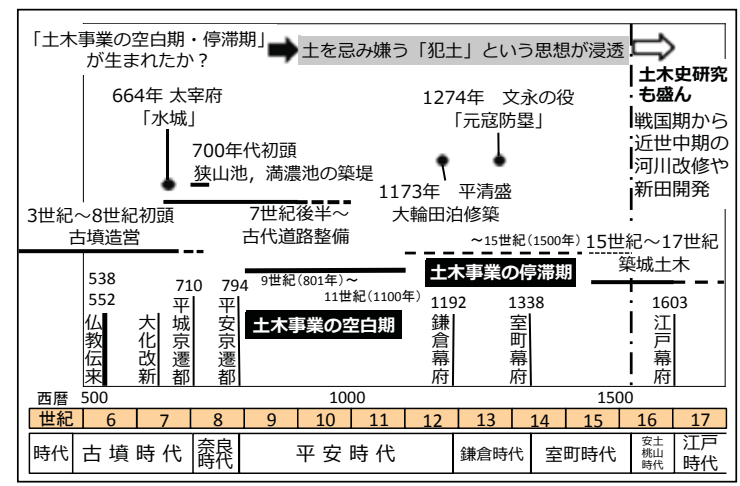

図-1 わが国の近世以前における社会基盤整備2) 
前述した軍事土木は行われていたが，現在の社会基盤に 通ずる事業は停滞していた。

\section{(2) 研究の目的}

江戸時代に入ると, 戦国時代の動乱は次第に収まって いった，民衆の生活が安定したことで，食糧増産を目的 とした河川改修や新田開発などが広く実施されるように なった 5)。 ののように，江戸時代以降に実施された土 木事業は，現代へと繋がる社会基盤整備の萌芽であった と考えられる（図-1）》．江戸幕府によって実質的に全 国統一がなされ，幕藩体制を維持するため, 連絡網とし ての道路整備は必須であったと推察される.

そこで本研究では, 江戸時代前中期において, 道路行 政政策がどのように進められてきたのか，江戸幕府の公 式記録として編纂された『徳川実紀』を読み解いて，そ の一端を明らかにしていくことを目的とした ${ }^{[1]}$.

一方で,「橋梁」に関する事項も, 重要な道路行政政 策の一つに数えられる. 当時は, ほとんどの橋梁が木構 造で洪水による流失や火災による破損があった。 『徳川 実紀』には，それらを含めて 100 項目を越える記述があ ったことから，「橋梁」は別項で報告することとした．

\section{(3) 研究の位置づけ}

本研究で対象とした江戸時代前中期における道路行政 政策に関して，これまでの先行研究を整理しておきたい

\section{a) 江戸幕府により整備された交通網に関する既往研究}

本研究で対象とした江戸幕府の道路整備に関寸る事項 は，交通史の分野で蓄積がある，丸山によると ${ }^{8)}$,

「江戸幕府は幕藩体制を形成・維持するために，戦国大 名の分国中心の交通体系から，江戸を中心とした五街 道を重要幹線とする一大交通体系への改編をめざし, みずからも三河・ 5 力国以来の伝馬制を拡充して, 関 東領国を基盤としつつさらに全国的なものに発展させ た.」

さらに，武部 91は江戸幕府がこれまでの分国中心から江 戸を中心とした交通体系へ変化させたことが指摘された。 また，その時代に形成された交通網については ${ }^{10)}$,

「幕府直轄の五街道およびその付属の街道と，各藩の大 名に実質的に委ねられていた脇街道から成っていまし た. これら大小の街道が，一つのネットワークを形成 して，江戸期日本の陸上交通を支えたのでした.」 五街道と主要な脇街道が幹線で，そこに脇道・横道が分 岐または延長され，ネットワークが形成されていったと いう ${ }^{11}$ 。このように，江戸を中心とした交通体系が江戸 幕府によって整備されたことは間違いないといえる.

\section{b) 江戸幕府が支配した道路とその職掌}

前項で示したように, 江戸幕府は五街道や脇街道を道 中奉行が実質的に支配していた ${ }^{12}$. 丸山 ${ }^{13}$ によれば,
「江戸時代，宿駅の取締まりや道路・橋梁など，道中一 切のことを総管したのが道中奉行である.」

とあり，道中奉行が支配した範囲は，種々の先行研究で 述べられている ${ }^{14,15)}$. 児玉によれば ${ }^{10}$,

「陸上交通としては江戸から四方に出る東海道・中山 道・甲州道中 ・ 日光道中 ・ 奥州道中の五街道を最重要 幹線とし，そのほか北国街道・水戸街道・佐倉街道な ど多くの脇街道があった。これらの主要路線における 交通の監理は政府が行い，初めは江戸の町年寄の奈良 屋市右衛門と樽屋藤右衛門らが事に当たったが，慶長 十九年（1614）に代官五味藤九郎が御宿奉行となって 駅伝のことを掌った．ついで万治二年（1659）に大目 付兼帯の道中奉行が設けられ，さらに元禄十一年

（1698）に勘定奉行から一名が兼任することとなって 幕末に及んだ。」

江戸幕府において, 道中奉行が主要街道を掌るまでの一 連の流れが示されている. そして, 武部 ${ }^{17}$ は道中奉行の 具体的な職掌を述べており,

「主要街道は諸大名の参勤交代の往来のために発達した といってよく，したがって道中奉行の直轄支配も，そ の取締りや便宜の上から定められたと見てもよいでし よう。道中奉行の職掌としては, 道中宿々の吟味（取 締り）, 訴訟審議, 道路・橋梁の普請や修復, 並木・ 一里塚の保全などでした。道中奉行の管轄する以外の 脇街道の管轄は，勘定奉行にありました．勘定奉行の 街道に対する責任は，道中奉行のような「支配」では なく, 「取扱い」であって, 普通にはこれらの街道の 実務は諸藩が実施していました。」

「支配」と「取扱い」は，どういったものかといえば18)， 「それは本州中央部のかなりの地域（五街道・付属街道 とその周辺のベルト地帯）では，幕府権力を体現する 道中奉行（大目付・勘定奉行）が, 関所一口留番所の 網羅的な配置によって政治・軍事的権能を補完しなが ら，諸藩など在地権力を媒介とせずに直接支配権を行 使（「支配」）したのに対し，その延長上の主要幹線

(脇街道) とその周縁部では, 財政的権能を主体とす る勘定奉行が, 在地権力を通じて間接的権力行使

（「取扱」）にとどまったことを示唆している.」 五街道は全国支配の根幹をな寸もので，幕府は，その一 帯に腹心の譜代大名・旗本（代官）を配置しながら，他 方では在地権力としての独自性を一定程度削減し，中央 集権的支配を貫徹させようとしていたという ${ }^{19}$ ．江戸幕 府による支配構造が直接的であるか間接的であるかにか かわらず，その体制は維持されていた。

\section{c) 各藩が支配していた道路網に関する既往研究}

江戸幕府が直轄で支配していた五街道や脇街道以外の 道路について ${ }^{199}$, その具体例として示されているのは非 常に少なく, 水口藩や名古屋藩（ママ）で実施された事 
業が挙げられていた ${ }^{201}$.

「諸藩の道路は, それが五街道筋の各城下・街道の場合, 道中奉行に伺ったうえで, 幕府役人など公儀関係の通 行に留意して修理を加え, 脇街道の場合も, 多くは藩 の法令などに道橋の保全・修理に関する条項を加え， 五街道に準ずる取扱いをしている。」

地方の主要幹線沿いは幕府の意向を伺いながら, 修理等 を実施していたと考えられる.

\section{d) 並木・一里塚の整備}

ここまで，江戸幕府が実施してきた道路行政政策につ いて，その支配体制を中心に既往研究を整理してきた. 次に，江戸幕府が関わった具体的な道路整備をみると， 並木と一里塚が挙げられていた ${ }^{21}$. 児玉によれば2),

「交通政策としての第一は道路の整備であるが，一里塚 を設けたり並木を植えて旅行者の便宜を計るほか，道 路の修繥と管理は沿道の宿や村に一定区間の責任を持 たせる方法を講じた。」

とあり，そのうち，並木については23)，

「宝暦 12 (1762）年には，従来の積極的な並木保護策 を徹底させ，五街道・脇街道など全国すべての往還並 木の植えつぎ，道幅の狭いところの修築，高割による 掃除丁場指定など詳細に規定し, 以後も触達（ママ） を繰りかえして励行させた. さらに, 諸藩の熊本藩, 会津藩などでも杉並木を植えた」

並木は，全国一律で徹底して植えられたというよりはむ しろ, 幕府の奨励や諸藩の努力によって漸次拡大した. 大島 ${ }^{24}$ も同様に，幕府は並木の保護に努め，絶えず育成 に腐心していたと述べている.

そのほか, 江戸幕府が関わった街道整備は, 本研究の

表-4 No.2 で後に示寸慶長 17 （1612）年の老中土井利勝 ら 3 名の連署で，道路，橋，堤の補修に関する『覚』が 出されたことを挙げている程度であった ${ }^{12,25)}$.

江戸幕府が関与しない事業としては，寛永 9 （1632） 年 (ママ) , 会津藩が八万人の人夫を募って白河街道全 線を改修し，峠路には平石を敷いたことが示されている 29. それ以外では, 補注[3]で示した京都と大津の間にあ る逢坂山と日ノ岡峠の難所で，享保 19（1734）年木食 養阿上人が改修を京都町奉行に願い出て, 元文元（1736） 年，車道三百間に白川石を敷きつめた日本最初の軌道舗 装が挙げられるにとどまっていた 27,28,29).

\section{e) 既往研究に関する調査のまとめ}

ここまで，本研究の対象としてきた江戸時代前中期に おける道路行政政策について整理してきた．江戸幕府は 五街道, 脇街道を道中奉行を兼ねた勘定奉行が管理して いた．また，地方においても，主要幹線沿いであれば幕 府の伺いを立てながら修理等を行っていた．このように， 既往研究では道路の管理やそれに関わる職掌などの支配 体制について多くの研究が蓄積されていた.
しかし，幕府および各藩とも個々の「道路」に関する 具体的な社会基盤整備については数例が挙げられている だけであった． 江戸時代前中期を通して断片的に明らか にされているに過ぎず，各時代の事績を積み上げて江戸 幕府が実際にどのような道路行政政策を実施していたか を述べた研究は見当たらない状況にあった。本研究では, 『徳川実紀』に掲載されたすべての記述を対象とし，そ のなかから社会基盤整備に関する事項を抜き出すことで, 江戸時代前中期における道路行政政策を明らかにした.

\section{2. 研究方法}

\section{(1) 『徳川実紀』の位置づけ}

本研究で用いる『徳川実紀』とは，『国史大辞典』30) によると，

「初代徳川家康より第十代家治までの江戸幕府将軍の事 歴を中心に叙述した史書. 第十一代家斉から第十五代 慶喜までは『続徳川実紀』と通称されている，江戸幕 府撰. 巻数は「御本編四百四十七冊, 御附録六十八冊, 成書例・総目録・引用書二冊, 通計五百十七冊」（総 目録末尾に記され，献上本の冊数）で，通し巻数はな い. 献上本に題された本書の総称は『御実紀』で, こ の総称は編集方針評議の段階で定められた。『徳川実 紀』という呼称は明治以後のものである.（中略）徳 川氏の立場からの叙述, 編纂時における対照の困難に よる年紀の混乱もみられるが，すべての史料は流麗な 平仮名交り文で統一し，原文をあまり崩さないで元の 形を存しようとする意図と成島司直の簡潔な要約は要 を得て, 近世研究の基幹書の一つである.『続徳川実 紀』は本編に続いて編集作業が勧められたが，結局未 完成で進献には至らなかった。（中略）編集方針は前 書と同様であったらしく, 体裁・構成は前代までのも のと全く同じでほとんど完成されているが，他は稿本 のままで，史料集の観がある（以下略）。」

と示される. 『徳川実紀』は公式記録であり, 江戸幕府 による一連の社会基盤整備の実態を把握できると考えら れる. 初代将軍の徳川家康から第 10 代の徳川家治まで の事績がまとめられた本史料を読み通し，そのなかから 社会基盤整備に関する事項を抜き出した。 なお， 『徳川 実紀』については，吉川弘文館『新訂増補 国史大系 徳川實紀 第 1 篇〜第 10 篇』 ${ }^{31)}$ 用いた.

次いで，第 11 代徳川家斉から第 15 代徳川慶喜が将軍 を務めた時代については，『続徳川実記』が存在するも のの未完であり, 主としてその内容は役職の変更や人事 異動等について記載されている程度であった，そのこと から, 本研究の対象からは外すこととした. 


\section{（2）江戸時代前中期の「道路」に関する記載事項}

江戸時代は表-1 で示したように，前期・中期・後期 の3期に分けられることが一般に言われている．本研究 では，前節で詳述した『徳川実紀』に記載されている初 代将軍の徳川家康から第 10 代徳川家治までの江戸時代 前期から中期を研究対象とした.

そして，『徳川実紀』の社会基盤に関する記述として， 築城（軍事土木），橋梁，道路，河川，㷋害等の記述が 掲載されていた，本研究では，そのなかからら道路」に 関するす心゙ての事項を抜き出した。主として，それらの 記述は江戸府内と五街道，脇街道に関するものを対象と しており，江戸幕府が「道路」に関連する法制度や維持 管理をどのように整備していたかを明らかにした。

\section{3.『徳川実紀』にみる「道路」に関する記述の 分類}

表-1 で示した『徳川実紀』に記載されている江戸時 代前中期（1603 年～1786 年）の「道路」に関する記述 は，110 項目が存在し，それらの分類を行った，その結 果，複数の項目にまたがる記述も存在したため，表-2 で示した 149 項目に分類することができた.

ある特定の道路を新規造成あるいは補修した「2．道 路施工」に該当する具体的な記述よりも，「1．規則の 制定」に関する事項が多くみられた。また，勝手な道路 改変の禁止（表-2 中 1(5)），民衆へ周知させるための高 札を設置（表-2 中 1(6)）するなど，道路使用者に対する 規則を制定した記述も存在した。

\section{4. 規則の制定}

\section{(1) 規格}

江戸幕府において，道路に関する「規格」を制定した という記述である．表-2の分類で示した「規格」に該当 し, 単位の制定をしたものがあった. その初出は, 慶長 9 （1604）年（表-3No.2）で,

「三十六町を以て一里とさだむ。豊富太閿諸國を檢地せ しめ。三十六町にさだめ。一里毎に堠塚を気づかしむ （ママ）. 此時又改て江戸日本橋を道程の始に定め.

七道に堠を築かれしとぞ。」

距離について，諸国で種々の単位を用いていたが，豊臣

表-1 江戸時代の時代区分

\begin{tabular}{|c|c|c|}
\hline 江戸時代 & 将軍 & 西暦 \\
\hline 前期 & 初代徳川家康～5代徳川綱吉 & 1603 年～1709年 \\
\hline 中期 & 6代 徳川家宣～10代徳川家治 & 1709 年～1786年 \\
\hline 後期 & 11 代徳川家斉～15代徳川慶喜 & 1787 年～1867年 \\
\hline
\end{tabular}

表-2『徳川実紀』にみる「道路」に関寸る記述の分類

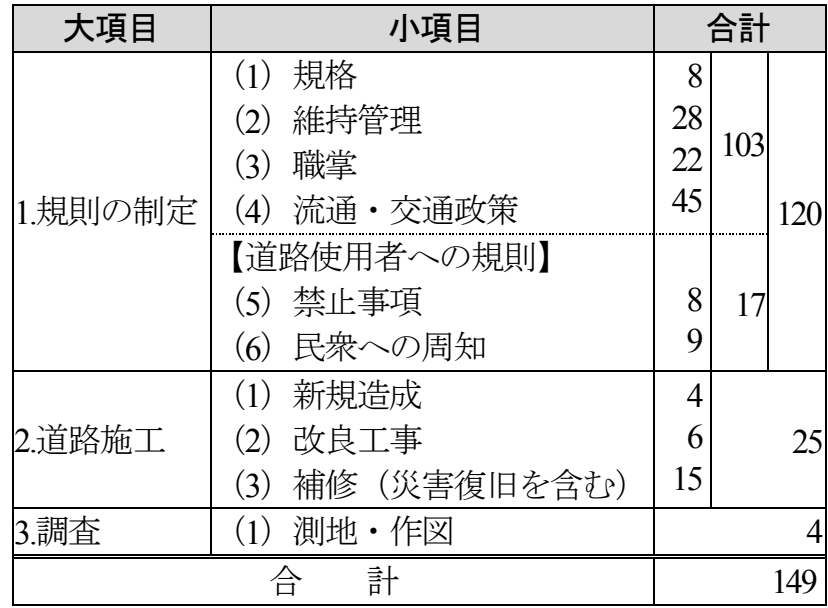

表-3『徳川実紀』にみる「規格」の項目

\begin{tabular}{|c|c|c|c|}
\hline . & $\begin{array}{l}\text { 西暦 } \\
\text { 和暦 }\end{array}$ & 目 & $\begin{array}{c}\text { 記載事項 } \\
\text { （斜線部は『德川実紀』に }\end{array}$ \\
\hline 1 & & 規格 & $\begin{array}{l}\text { 右大将殿の命として. 諸國街道一里毎に堠塚（世に一 } \\
\text { 里塚といふ）を築がしめられ. 街道の左右に松を植し } \\
\text { めらる. 東海中山兩道は永井彌右衛門白元. 本多左大 } \\
\text { 夫光重. 東山道は山本新五左衛門重成. } \\
\text { 築一里塚街道左右植松 }\end{array}$ \\
\hline 2 & 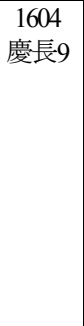 & 規格 & $\begin{array}{l}\text { 世に傳ふる所は. 昔より諸國の里數定制ありといへど } \\
\text { も. 國々に異動多かりしが. 近世織田右府領國の内に } \\
\text { 堠塚を築ぎ. 三十六町を以て一里とさだむ. 豊富太閤 } \\
\text { 諸國を檢地せしめ. 三十六町にさだめ. 一里毎に埃塚 } \\
\text { を気つがし. 此時又改て江戸日本橋を道程の始に定 } \\
\text { め. 七道に堠を築かれしとぞ. 其時大久保石見守に. } \\
\text { 堠樹にはよい木を用ひよと仰ありしを. 長安承り誤り } \\
\text { て榎木を植しがいまにのこれりとぞ } \\
\text { 以江戸日本橋爲道程始 }\end{array}$ \\
\hline 3 & 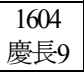 & 規格 & 命ぜられたる諸國堠塚ことごとく成功す \\
\hline 4 & $\begin{array}{c}1604 \\
\text { 慶長 } 9\end{array}$ & & $\begin{array}{l}\text { 路程の里數も. 織田右府の時より三十六町をもて一里 } \\
\text { と定め. 一里ごとに堠を築しめて表識せられしを. 豊 } \\
\text { 臣家にても彌遵行有しが. 君關東へ移らせ給ひし後. } \\
\text { 同じく一里毎に堠を築き. その上に榎の木を植しめ給 } \\
\text { ふ. (このとき松の木植んと申上しに. 餘の木を植よ } \\
\text { と仰有しを承り違ひて. 榎の木をうへしいい) } \\
\text { 一里塚築造 }\end{array}$ \\
\hline 5 & \begin{tabular}{|l|}
1604 \\
慶長 9
\end{tabular} & & 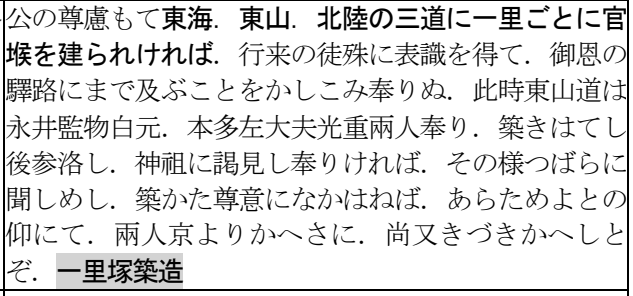 \\
\hline 6 & $\begin{array}{c}1649 \\
\text { 慶安 } 2\end{array}$ & & $\begin{array}{l}\text { 道溝の狭きを少しひろげ. 曲りたる路河を直にせん事 } \\
\text { をこひ. また早水の害をいとひて. 溜池あるは落堀. } \\
\text { 河防等をこひ出るに於ては. 検地心得 }\end{array}$ \\
\hline 7 & $\begin{array}{c}1657 \\
\text { 明暦3 }\end{array}$ & & 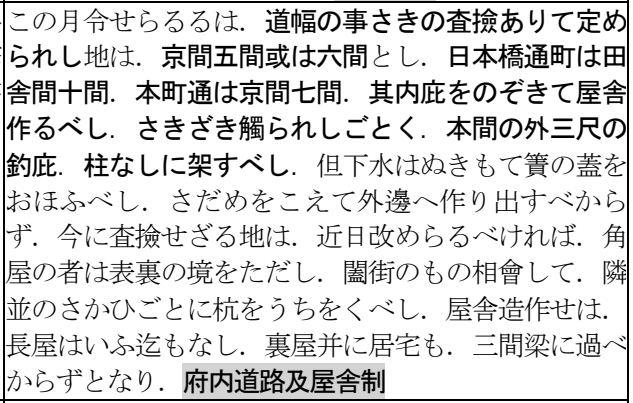 \\
\hline 8 & $\begin{array}{c}1657 \\
\text { 明暦3 }\end{array}$ & & 上記と同一の記述あり \\
\hline
\end{tabular}


秀吉の検地で36町を1里（約 $3.9 \mathrm{~km} ）$ とした．その後，七 道（五畿七道の七道を指寸カ）には堠塚を築き，道路の 起点は江戸日本橋に定めた。 一方で, 表-3 No.1には七道 と限らず，諸国街道一里毎に堠塚が築かれたとある。 そ の堠塚は，いわゆる一里塚で，里程を示寸堠樹が併せて 植えられた（表-3No.4にも同様の記載）。

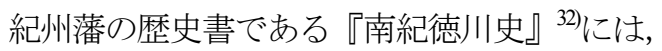

「東海道奥州木曾路等道路を作るへき由被仰出道の廣さ 五間三十六町を一里として一里塚を築き木を植えしむ」 東海道，奥州街道，木曽路（中山道）では，一里塚の築 造に加えて，街道の幅員を5間（約9.09m）としたことも 付言されていた. このように, 都市間道路に一里塚を設 ける明確な「規格」が定められた。

また，明暦3（1657）年（表-3 No.7， No.8）に発生した 明暦の大火後, 江戸府内の道路幅員が規定された.

「道幅の事さきの査撿ありて定められし地は. 京間五間 或は六間とし. 日本橋通町は田舎間十間. 本町通は京 間七間．其内庇をのぞきて屋舎作るべし．」

道路の幅員を京間5間（約9.09m）あるいは6間（約10.9m） とし，日本橋通町は田舎間10間（約 $18.2 \mathrm{~m} ） ，$ 本町通は 京間7間（約12.7m） と定めた.

さらに，表-3No.7には，

「其内庇をのぞきて屋舎作るべし，さきざき觸られしご

とく. 本間の外三尺の釣庇. 柱なしに架すべし.」 建物の庇は釣り庇とし，街路に柱を立てないよう沿道の 建築規制についても記載されていた.

このように，幕府の基幹となり得る「規格」に関する 事項は，江戸時代前期のみ記載があり，明暦3（1657） 年以降で「規格」に関する記述はみられなかった。

\section{(2) 維持管理}

江戸幕府が，道路の維持管理を実施するために定めた 制度である. 元和2（1616）年（表-4No.3）には,

「前々のごとく道途橋梁絶ず修理すべし，もし緩怠せば. 其地の代官過料として．五貫文出さしむべしとなり。」 道路や橋梁については絶えず修理し, 維持管理を吝った 場合，過料を支払わなければならなかった。明暦 3 （1657）年にも（表-4 No.12）,

「此月令せらるるは．市井の屋舎營作のとき地を修築せ ば. 道の兩邊高低なきやうになすべし. 并に大路は. 隣街の高低にならひ築くべし，をのがままにきづく事 あるべからずとなり。」

建築物を造営する際, 道路の両端は高低がないよう平ら にすること，大路では縦断勾配がつかないよう隣街の高 低に倣い，自分勝手な整地をしないように定められた

（表-2「1(5)禁止事項」にも該当）。

慶長 17 （1612）年の記述（表-4 No.2）をみると, 道路 を維持管理していくうえで, 具体的な施工仕様が定めら
れていた.

「十六日道路堤防の制を仰下さる. 大道小路とも馬さく りの所は．あるは砂あるは石もて堅固にならし，道の 側には水路をうがつべし．泥滑の所も砂石もて堅固な らしむべし，堤防の芝生を剪剥すべからず．馬さくり の所は．土をもて堅固にす心゙し，道路よろしき地にみ だりに土を敷べからず（以下略）。」

泥で滑りやすい箇所も含めて，道路の表面を砂あるいは 石を用いて堅固にすべきと示されていた，さらに，道路 の両端には水路を設置することや良好な状態にある道路 には分別なく土を敷かないようにせよとも書かれていた。 これらの記述は，現在における施工や維持管理に通ずる ものであろう。

享保 5（1720）年（表-5 No.28）の記述をみると, 「二日令せらるるは．武家市井辻番所．髪結所より．定 りて掃除する地は. 怠りなく掃除すべき旨に命じ.」 とあり，道路の掃除を実施することも制度として定めら れていた.このように，『徳川実紀』で記載されている 「維持管理」については江戸時代前中期を通して偏りな く記載されていた。

\section{a)「巡視・巡察」に関する事項}

維持管理として, 各地を巡りながら道路の状況を確認 する「巡視・巡察」が行われていた。「巡察」について, 寛永 10（1633）年（表-4No.6）の記述には,

「松平伊豆守信綱. 大目付井上筑後守政重. 柳生但馬守 宗矩は. 明年御上洛によて. 各驛御旅館并道路巡察命 ぜられいとま給ふ。」

橋梁や各驛を含む道路の「巡察」を行うように命じた記 述が示されていた（表-4 No.4，No.7，No.8，表-5 No.15，

No.22, No.26) .

そして，「巡視」について寛文 4（1664）年（表-5 No.17）の記述をみると，

「けふ令せらるるは．こたび關東の國々巡視命ぜらるる により．往還の便を得べきため．道路．橋梁を修めし むべし.」

とある．関東地方の国々を「巡視」して，滞りなく往来 できるよう道路や橋梁を修理するように命じた．そして, 「巡視」の事項は表-5 No.17, No.19, No.25, No.27 にも 示されていた.

\section{(3) 職掌}

江戸幕府において，「道路」に関する奉行の職掌変更 やその業務内容に触れた記述は22 項目で存在した.

\section{a) 普請奉行}

一般に「普請奉行」は，土木全般を掌っていたと考え られている.『土木用語大辞典』33)の「普請」には， 「江戸時代の土木・建築を担った職務の長として作事・ 普請・小普請の下三奉行, および勘定奉行があった. 
表-4 『徳川実紀』にみる「維持管理」の項目（1/2)

\begin{tabular}{|c|c|c|c|}
\hline No. & $\begin{array}{l}\text { 西暦 } \\
\text { 和暦 }\end{array}$ & 項目 & $\begin{array}{c}\text { 記載事項 } \\
\text { （斜線部は『徳川実紀』に記載の脚注） }\end{array}$ \\
\hline 1 & \begin{tabular}{|c|}
1609 \\
慶長 14
\end{tabular} & 維持 & $\begin{array}{l}\text { また江戸府内道路を修築すべしと關東の輩に課せら } \\
\text { る. 江戸府内道路修築 }\end{array}$ \\
\hline 2 & \begin{tabular}{|c|}
1612 \\
慶長17
\end{tabular} & $\begin{array}{l}\text { 維持 } \\
\text { 管理 } \\
\text { 禁止 } \\
\text { 事項 }\end{array}$ & 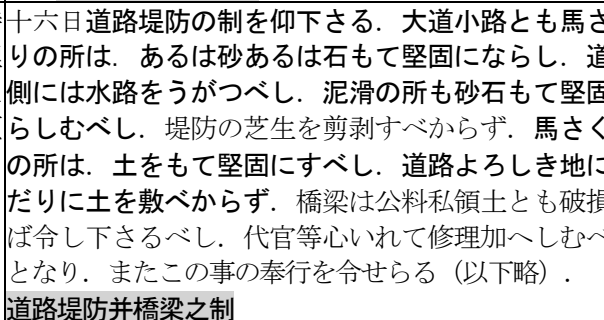 \\
\hline
\end{tabular}

31616 維持前々のごとく道途橋梁絶ず修理すべし.もし緩怠せば. 元和2 管理其地の代官過料として．五貫文出さしむべしとなり

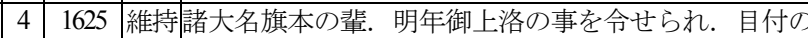
寬永2 管理輩には毎驛行殿橋梁巡察の事命ぜらる. 交通

551626 維持東海道中の諸大名城主領主．共に行路を修治し驛館を 寛永3 管理經營し．嚴石を埋．橋梁を新につくり心をつくしけり

61633 交通松平伊豆守信綱. 大目付井上筑後守政重. 柳生但馬守 宽永10 維持宗矩は．明年御上洛によて．各驛御旅館并道路巡察命 管理ぜられいとま給ふ。

\section{松平信綱等被命巡察上洛各驛旅館道路}

71644 交通十六日國廻目付小笠原孫座衛門某. 今福次大夫勝正京 正保元維持坂までの驛路巡察．大番天野傳左衛門重時。中根茂助 管理正次は西城大手橋改架奉行命ぜらる.

81646 維持大番松田六郎左衛門定平. 飯河新右衛門直信. 府より 正保3 管理大坂迄の驛々道橋を巡察し．地圖を造るべしと仰付ら 作図れ腵給ふ. 令製江戸大坂間驛路圖

91655 維持市應の地. 火變に備ふる井は. 一町のうち兩㥧に八つ 明暦元管理つほるべし．但その所は左右そのなみをよくすべし 補修一町六十間にあまるは十ほるべし．横町并に會所は左 災害右に二ほるべし，かた町は一町に四ほるべし，但古よ り井多くありて。制數にこえたるは苦しからず．其ま またるべし．數すくなき地は．さだめのごとく堀へ し．もし商賣の妨となる地は。地面高低にならひて。 蓋をおほひをくべし．上水不通の地は．前令水桶の 外. 一町兩煩に水桶八埋め置て。一月に一たび水をか 人．常に水盡ざるやうになし．是もふたをおほひをく ベしとなり。爲防火令堀井於市街

101648 維持この月令せられしは. 市井泥濘の道路は. 浅草砂に海 慶安元管理砂まじへ．道途高低なく中高に築くべし．芥ならびに 禁止泥もて街道を築くべからず. 下水の樋井に路傍の溝渠 事項雍埋せざるやう塵芥を除くべし．もしそむくものは曲 事たるべしとなり．道路下水制

111655 維持よて目付の屬吏をつかはし. 道路掃除の事を督せしめ 明暦元管理らる。（中略）又本誓寺より千住驛の間は．普請奉 職掌行. 道奉行掃除をなし.

\section{依韓使日光登山道中警衛井掃除}

121657 維持此月令せらるるは. 市井の屋舎營作のとき地を修築せ 明暦3 管理ば．道の兩邊高低なきやうになすべし．并に大路は． 禁止隣街の高低にならひ築くべし．をのがままにきづく事 事項あるべからずとなり．府内屋舎營作制

131659 維持御旅館の事奉はりし大名に仰下さるるは. 行殿改造す 万治 2 管理る事あるべからず。但軽く修繥すべし，道途は歩みや 禁止すき程に作り。酒掃のみして芝を付. くり石敷事ある 事項べからず．并にあらかじめ道途に人おほく付置べから ず. 路傍に湯水を備へ置事は. 三里ほど間を隔てて一 所づつあるべし. 日光社参將軍宿城令條

141660 維持市中一町のうち. 木戸の左右に手桶各三十．片町は十 寛文元管理五出して水を貯べし．梯は一町に六づつ．片町三づつ 補修設べし．表一間半より四間半迄の家は手桶三づつ．戸 災害の内外心のままに設べし，五間より九間半迄は五つ つ。南間より二十間までは十づつ前のごとく設置へ し. 水道なき地は，木戸際に水桶一を設置．手桶．梯 は十月晦日を限としてつくりたて置べしとなり消防制
表-5『徳川実紀』にみる「維持管理」の項目

\begin{tabular}{|c|c|c|c|}
\hline №. & $\begin{array}{l}\text { 西暦 } \\
\text { 和暦 }\end{array}$ & 項目 & $\begin{array}{c}\text { 記載事項 } \\
\text { （斜線部は『徳川実紀』に記載の脚注） }\end{array}$ \\
\hline \begin{tabular}{|l|}
15 \\
\end{tabular} & $\begin{array}{l}1662 \\
\text { 寛文2 }\end{array}$ & 交通 & 京坂井に諸驛地震のさま巡察ぜられいとまたまふ. \\
\hline
\end{tabular}

161662 維持此月令せらるるは. 市井にそへる城溝并に各處の溝洫 寛文2 管理浚利の事. こたび命ぜられたれば. 告竣の後. 堰坂あ るはしがらみ.あるは石垣にても。心のままに其岸の 形にしたがひつくるべし．尤少しも築出すべからず。 市中あしき道路は. こたび浚利の泥土をもて.心のま まにつくるべし．こたび命ぜられし塵芥載する船．日 本橋より南は三日。十三日。昍。一月三回づつ。 その日をさだめ．月ごとに各所の河岸へ船をよせ．其 市井の塵芥を捨しむべしとなり。

法度（溝渠道路 塵芥船）

17 寛文 4 交通けふ令せらるるは. こたび關東の國々巡視命ぜらるる 1664 補修により。往還の便を得べきため。道路. 橋梁を修めし 維持むべし．収穫の時なれば掃除等なすべからず。一切贈 管理遺あるべからず．巡視のともがら驛々にて．米豆など その郷估もてうりあたぶべ．すべて物價．常時のご とくうらしむべし．關東諸國巡視道路宿泊令條

181666 維持放鷹の地は常に令なしとも. 道途. 橋梁をこたりなく 寞文6 管理つくるべし. 各國村里下知狀

191667 維持東海. 東山兩道巡視にまかりし使番溝口源右衛門信 寛文7 管理勝. 小姓組川勝孫四郎廣有. 書院番堀主膳親泰.

201696 維持市井火災のとき. 水の便よからむため. 是迄にある所 元禄 9 管理の水桶の外に. 一町左右各二づつ新に設くべし. 其桶 補修徑二尺五寸．高三尺たるべし．井寸くなき地か．ある

災害は水のたよりあしき所は. 左右に各三づつたるべし. 折廻したる宅地は．二十間に一づつをくべし．もとも 常に水貯ふべしとなり。防火水桶制

\section{6 維持道路は高低をならし酒掃すべし.} 元禄 9 管理防火制

221698 交通少老米倉丹後守昌尹京攝河功. 東海驛路巡察の事命ぜ 元禄11維持らる.

管理

231707 維持酒井左衛門尉忠眞. 本多吉十郎忠孝. 眞田伊豆守幸道 宝永 4 管理は諸驛修築の助役を命ぜらる.

交通諸驛修築助役

241707 維持此月市井に令せらるるは. 街路をよび河岸の雪并に砂 宝永 4 管理を. 城隍へ寸つる聞えあり．今より後雪砂はいふまて もなし．何によらず隍中へすつべからず。もし違犯せ ばとがめらるべしとなり．江戸城隍雪砂捨棄禁制

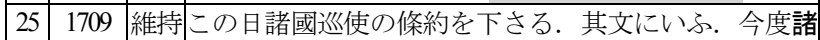
宝永6 管理國に巡視の御使立らるるといいど．地圖を製し．人馬 作図の數を撿することあるべからず，御朱印券にのせられ し外の人馬を用ゆるときは．其價を出すべし．城主. 領主より使者音物ををくるべからず。郷導の者なくて かなはざる時は。御使より斷るべし。道すがら酒掃す ベからず．有来る道橋．往来のたよりよからざる所 は．此かぎりにあらず．驛舎ことさら造營し．茶亭な ど新に設くることあるべからず. 諸國巡使條約

261711 交通大目付松平石見守乗邦驛路巡察はてて歸謁す。勘定の 正徳元維持ともがらもおなじ.

管理

271712 維持十六日諸國巡視の御使下さるるにより令せらるるは. 正徳 2 管理こたび御料の國々巡視の御使通行の道途. 酒掃ならび に道橋搆造なすべからず，送迎の者出す事あるまじ． (以下略) 諸國巡使條目

281720 維持二日令せらるるは. 武家市井辻番所. 髪結所より. 定 享保5 管理りて掃除する地は．怠りなく掃除すべき旨に命じ．橋 欄の下．あるは橋側に塵芥あらば取捨しめ．水はしり よくすべし．さる定めもなき辻板書見廻りの地なら ば．番人常に心用ひ．塵芥を橋詰等に捨ざるやうに し．もし見廻らざるうちに捨たるは，見廻りのとき取 寸てて. 水はきよからしむべしとなり．道路掃除制 
このうち, 普請奉行と勘定奉行が主として土木を担当, 作事・小普請が建築や修繥等を担当した。（中略）普 請奉行は江戸城の石垣や堀の普請, 各所の土居, 石垣, 堀浚い, 神田 -玉川上水, 江戸中の屋敷割や明屋敷 拝領屋敷の請取り・請渡し等を管掌した。」

とある。その『徳川実紀』には，「道路」に関わった

「普請奉行」の記述が3ヶ所でみられた。明暦元（1655） 年（表-6No.4）には,

「目付の屬吏をつかはし. 道路掃除の事を督せしめらる.

（中略）又本誓寺より千住驛の間は. 普請奉行. 道奉 行掃除をなし.」

普請奉行は，道路掃除を監督していたことが示されてい た．続いて，享保4（1719）年の記述には（表-7 No.13）, 「三日本所奉行の職を停廢せらる．よりて武家邸宅のこ とは普請奉行. 道路. 橋梁. 水道のことは. 勘定奉行

より指揮すべしと命ぜらる.」

とある.「普請奉行」が建築に関わるものを掌り，「勘 定奉行」が道路，橋梁，水道等の社会基盤整備へ関与す るようになったと記載されていた。これは，「普請奉行」 の職掌を示した重要な記述であると考えられる，その

「勘定奉行」について，元禄11（1698）年（表-6 No.10）

表-6『徳川実紀』にみる「職掌」の項目 $(1 / 2)$

\begin{tabular}{|c|c|c|c|}
\hline No. & \begin{tabular}{|l} 
西暦 \\
和暦
\end{tabular} & 項目 & $\begin{array}{c}\text { 記載事項 } \\
\text { （斜線部は『徳川実紀』に記載の胠 }\end{array}$ \\
\hline 1 & $\begin{array}{l}1628 \\
\text { 寞永5 }\end{array}$ & & 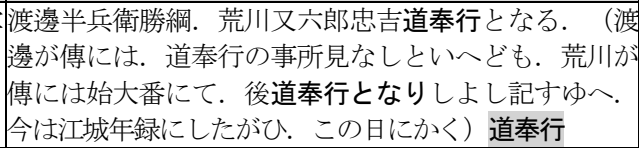 \\
\hline 2 & \begin{tabular}{|l}
1635 \\
寛永12
\end{tabular} & 職掌 & $\begin{array}{l}\text { 普請奉行. 小普請奉行. 道奉行は伊豆守信綱．豊後守 } \\
\text { 忠秋. 加賀守正盛三人の沙汰たるべしさされど非常の } \\
\text { 營築井に宅地割の事は. 大炊頭利勝. 讃岐守忠勝には } \\
\text { かりあぶし. }\end{array}$ \\
\hline 3 & \begin{tabular}{|c|}
1638 \\
寛永15
\end{tabular} & 職掌 & 衛門長教. \\
\hline 4 & \begin{tabular}{|c|}
1655 \\
明暦元
\end{tabular} & & $\begin{array}{l}\text { 目付の屬吏をつかはし. 道路掃除0 } \\
\text { る.（中略）又本誓寺より千住驛の } \\
\text { 道奉行掃除をなし. 依韓使日光登山道 }\end{array}$ \\
\hline 5 & \begin{tabular}{|c|}
1655 \\
明暦元
\end{tabular} & 職掌 & $\begin{array}{l}\text { 佐藤勘右衛門吉次韓聘によて. 駿河薩埵咔道作奉行命 } \\
\text { 尤られ腵給ふ. 駿河薩埵峠道作奉行 }\end{array}$ \\
\hline 6 & $\begin{array}{c}1686 \\
\text { 貞享3 }\end{array}$ & & 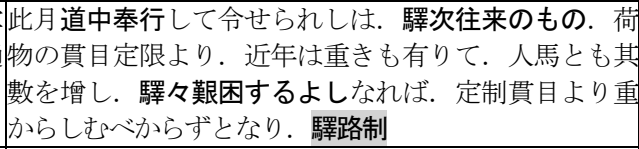 \\
\hline 7 & $\begin{array}{c}1687 \\
\text { 貞享4 }\end{array}$ & & $\begin{array}{l}\text { 市人は町奉行. 公料は代官. 諸驛は道中奉行. 私領は } \\
\text { 地頭へ. 其よしうたへ出べしとなり. 道中奉行 }\end{array}$ \\
\hline 8 & $\begin{array}{l}1693 \\
\text { 元禄6 }\end{array}$ & 職掌 & $\begin{array}{l}\text { 十日府内上水今まで町奉行の所屬たりしが. 此のち道た } \\
\text { 奉行に其事をつとめしむ. よて新に所屬の同心を置し } \\
\text { めらる. 府内上水爲道奉行支配 }\end{array}$ \\
\hline 9 & $\begin{array}{l}1693 \\
\text { 元禄 } 6\end{array}$ & 職掌 & $\begin{array}{l}\text { この日令せらるるは. 水道の事は道奉行の所管たらし } \\
\text { むれば. 今より後うたへ出る事あらば. 道奉行へうた } \\
\text { へて指揮うくべしとなり. }\end{array}$ \\
\hline \begin{tabular}{|l|}
10 \\
\end{tabular} & \begin{tabular}{|c|c|}
1698 \\
元禄11 \\
\end{tabular} & 職掌 & $\begin{array}{l}\text { 七日勘定奉行松平美濃守重良. 大目付神尾備前守元清 } \\
\text { と共に. 驛路の事奉るべしと仰付らる. }\end{array}$ \\
\hline \begin{tabular}{|l|}
11 \\
\end{tabular} & $\begin{array}{c}1705 \\
\text { 宝永2 } \\
\end{array}$ & & $\begin{array}{l}\text { 七日勘定奉行石尾阿波守氏信驛路の事令ぜらる. } \\
\text { 勘定奉行石尾氏信掌驛路事 }\end{array}$ \\
\hline 12 & $\begin{array}{l}1707 \\
\text { 宝永4 }\end{array}$ & 補修 & $\begin{array}{l}\text { こたびの地震により．諸道堤防破損の所. 速に修理す } \\
\text { べきむね. 井上河内守正岑. 少老稻垣對馬守重富に仰 }\end{array}$ \\
\hline
\end{tabular}

の記述をみると，

「七日勘定奉行松平美濃守重良. 大目付神尾備前守元清 と共に。驛路の事奉るべしと仰付らる.」

驛路の事を掌るようになったことも記されていた（表-7 No.11，No.18にも同様の記述）。以上のことから，「普 請奉行」は，道路掃除等を行っていたものの，先述の享 保4（1719）年（表-7 No.13）の項目であったように，道 路造成などの土木工事に関与していなかったとみられる.

b) 道奉行

「道奉行」は, 江戸府内の道路, 水道を掌っていたと される. 元禄6（1693）年（表-6 No.8, No.9にも同様の記 述）で示されているように，

「十日府内上水今まで町奉行の所屬たりしが。此のち道 奉行に其事をつとめしむ. よて新に所屬の同心を置し めらる.」

この年に玉川上水及び神田上水の管理が，町奉行から 「道奉行」へ変更された.

しかしながら, 享保5（1720）年には（表-7 No.16）,

「けふ道奉行の職を廢せらる。」

とあり，「道奉行」は廃職となったものの，同年（表-7 No.17）には,

表-7 『徳川実紀』にみる「職掌」の項目 (2/2)

\begin{tabular}{|l|l|l|c|}
\hline No. & $\begin{array}{l}\text { 西暦 } \\
\text { 和暦 }\end{array}$ & 項目 & 記載事項 \\
(斜線部は『德川実紀』に記載の脚注)
\end{tabular}

131719 職掌三日本所奉行の職を停廢せらる。よりて武家邸宅のこ 享保4 とは普請奉行. 道路. 橋梁. 水道のことは. 勘定奉行 より指揮すべしと命ぜらる. 本所奉行停廢

141719 職掌本所奉行停廢せられしにより. 水道并に道橋等. 此後 享保4 代官指揮すべしとなり.

151719 職掌けふ令せらるるは. 寛永増上兩寺の御参. または御鷹 享保4 狩の時. 道のほとりに溝泥を乾しをきしは. その所を 書付出せる事なるが. 今より後は道奉行撿察して事足 るべし．ただし初てならせ給ふ道のみ，さきざきのこ とくなるべしとなり．道路制

161720 職掌けふ道奉行の職を廢せらる. よて再びこの職を置るる 享保5 までは. 目付よりか将つかふまつり。下吏をも指揮寸 心゙しと命ぜらる. 道奉行停廢

171720 職掌けふ令せらるるは. 府内水道の修理する時. 水源を護 享保5 る商人にはかりて。修理加へし事もあれど. 今よりは いささかの修理たりとも. 必道奉行の指揮を請べし. 道奉行水道監視するとて，宅地のうちにかかる流を見 る事もあるべければ，斷あるまま，見せしむべしとな り. 道奉行管水道修理

181721 職掌廿日勘定奉行筧播磨守重賢驛路の事奉はる 享保6 交通

191724 職掌けふ勘定奉行筧播磨守重賢驛路の事奉はりしをゆるさ 享保9 交通れ。稲生下野守正武をしてこれにかはらしむ. また驛 路の事つかふまつりし興力. 同心を停廢せらる.

20 享保7 補修この日代官小宮山本之進昌世に命ぜられしは. 佐倉. 1722 職掌小金等の牧地. 新田. 林などのこと. 聞えあげしごと く．心にまかせ處置すべし．野牧の道途修理なども． 牧士の長綿貫夏右衛門に指揮してはからふべしとな り。代官小宮山昌世被命佐倉小金牧場開拓植杯

211728 職掌十六日道奉行か将し書院番大久保三大夫忠固兼職をゆ 享保13 るされ. 久しく道奉行勤めしを裹めせられ。

221739 職掌玉川上水の事. 今より町奉行に隸せられ. 道奉行は道 元文4 途の事のみ奉はるべしと命ぜらる. 町奉行管玉川上水 
「けふ令せらるるは．府内水道の修理する時．水源を護 る商人にはかりて。修理加一し事もあれど．今よりは いささかの修理たりとも，必道奉行の指揮を請べし． 道奉行水道監視するとて.」

水道の修理を行う際，「道奉行」へ指揮を仰ぐ必要性が あったため，再び任命された．その後の元文4（1739） 年（表-7 No.22），

「玉川上水の事. 今より町奉行に隷せられ。道奉行は道 途の事のみ奉はるべしと命ぜらる.」

玉川上水の役務を町奉行へ返還し，「道奉行」は道路に 関する事のみを掌る役職となった。

その後, 『徳川実紀』が対象とした時代からは外れる が，明和5（1768）年には再び廃職となり，「道奉行」 は普請奉行の所管になったという ${ }^{34)}$. 「道奉行」は，水 道に関する事を掌り，その役職が廃せられたり再び設置 されたり不安定であった．さらに，「道路」の具体的な 職掌が『徳川実紀』に記述されておらず不明であった。

\section{c) 道中奉行}

『徳川実紀』では，「道中奉行」について4ヶ所の記 載があった. 貞享4（1687）年の記述（表-6 No.7）には, 「市人は町奉行. 公料は代官. 諸驛は道中奉行. 私領は 地頭へ．其よしうたへ出べしとなり。」

その他の記述も同様で，驛路等の宿場を「道中奉行」が 掌っていたとされる. その職掌は, 五街道宿駅の取締り, 宿場の公事訴訟，街道の橋の修復，並木の管理，伝馬，

旅宿飛脚，助郷など道中に関する一切を掌っていたとさ れる ${ }^{35}$. しかし，『徳川実紀』には，道路修築等に携わ ったという具体的な記述が存在しなかった.

\section{d）その他の道路に関わった官職}

ここまで，「道路」に関わった職掌について述べてき た．本項では，それ以外で「道路」に関与した職掌につ いて触れることとした.

宝永4（1707）年（表-6 No.12）には，

「こたびの地震により．諸道堤防破損の所．速に修理す

べきむね. 井上河内守正岑. 少老稻垣對馬守重富に仰 付らる.」

これは，太平洋沖を震源とする巨大な宝永地震で，その 被害を受けた道路や堤防の修築を幕府中枢の職掌であつ た井上河内守正岑 (老中職) と稻垣對馬守重富（若年寄 職) が指揮した ${ }^{[2]}$.このような大災害では, 幕府直轄で 道路復旧等の指揮にあたっていたと考えられる.

享保 7 （1722）年（表-7 No.20）の記述をみると, 「この日代官小宮山圭之進昌世に命ぜられしは. 佐倉. 小金等の牧地. 新田. 林などのこと. 聞えあげしごと く，心にまかせ處置す心゙し，野牧の道途修理なども，」 牛馬を放牧する所の道路修理を代官である小宮山圭之進 昌世が実施した。「道路」の修築等は, 「道奉行」や 「道中奉行」ではなく, 勘定奉行や代官がその都度任命
されて実施していたと考えられる.

\section{（4）流通 ·交通政策}

『徳川実紀』の「道路」に関する記述のなかで，「交 通および流通政策」が 45 項目で最も多く示されていた。

a) 制度の制定および驛に関する職掌の変更

慶長 16（1611）年（表-8 No.2）,

「此月板倉伊賀守勝重. 米津清右衛門正勝. 大久保石見 守長安. 連署して驛路の令を下さる.」

江戸幕府が成立した 17 世紀初頭に驛路の令が制定され

た，その驛，驛路を司る役人について，元禄 11（1698） 年（表-9No.29）には,

「七日勘定奉行松平美濃守重良. 大目付神尾備前守元清 と共に. 驛路の事奉るべしと仰付らる.」

驛路等を掌る役人の変更が都度行われていたことが示さ れていた（表-10No.31，No.32，No.38，No.39）。

\section{b) 通行料 ・ 運送料の設置および改定}

元和 2（1616）年（表-8 No.4）には,

「是月令せられしは．傳馬をはじめ駄賃荷物。いずれも 一駄四十貫目たるべし，府より品川まで往還荷物。一 駄鐚錢三十四文. 板橋へは三十九文. 人夫賃は馬の半 たるべし.」

とあるように, 通行料や荷物の運搬料である駄賃は, 都 度改正が行われていた（表-8 No.8，No.10，表-9 No.22，

No.24, No.26, No.27, 表-10 No.35) .

明暦2（1656）年（表-8 No.13）,

「また御側所屬の圖目付を東海道の驛路につかはされ， 毎驛の人馬遅滞すべからざる旨令せしめらる.」

とあり，寛文 5（1665）年（表-9 No.19），

「中山道諸驛に令せらるるは．畫夜風雨のときも．とど こほらず出すべし，毎驛に馬五十疋を備へ．大名一家 に一日に二十五㱜出すべきむね，さきに令せられぬ。」 駅では，荷物を運搬する馬を常時待機させ，たえず出動 できるようにせよなど，物流が滞ることのないよう，令 が出されていた（表-8 No.16，表-10 No.30，No.40）。

一方で，貞享 3（1686）年（表-9 No.26）,

「此月道中奉行して令せられしは. 驛次往来のもの. 荷 物の貫目定限より。近年は重きも有りて。 人馬とも其 數を增し，驛々艱困するよしなれば，定制貫目より重 からしむべからずとなり」

今日, 段々と荷物が重くなり, 往来する人や馬の数が増 え，各驛は困っているとの記述もみられた．

\section{c) 滞りなく通行することができる道路環境の確保}

宝永 6 （1709）年，「道路」の通行に支障が出ないよ う定められた。

「また令せられしは. 牛馬あまたひきつづき. 往来のさ またげすべからざる旨．しばしば令すといいども，頃 日また猥りなるよし聞ゆ。ささあらむには．此後牛引者 
表-8 『徳川実紀』にみる「流通・交通政策」

$(1 / 4)$

\begin{tabular}{|c|c|c|c|}
\hline Vo. & 西暦 & 項目 & $\begin{array}{c}\text { 記載事項 } \\
\text { (斜線部は『德川実紀』に記載の脚注) } \\
\end{array}$ \\
\hline 1 & \begin{tabular}{|c|}
1604 \\
慶長 9 \\
\end{tabular} & 交通 & $\begin{array}{l}\text { 十一月二日彦坂小刑部元成より戸塚の驛に. 藤澤. } \\
\text { 奈川と同じ四驛馬のことつかまつるへしと令す. }\end{array}$ \\
\hline 2 & \begin{tabular}{|c|}
1611 \\
慶長 16 \\
\end{tabular} & & 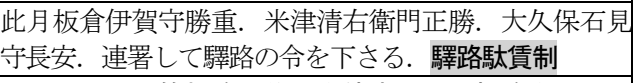 \\
\hline 3 & $\begin{array}{ll}1614 \\
161 \\
\end{array}$ & & $\begin{array}{l}\text { またこのころ箱根路の往還を停廢し. 足柄路を通行せ } \\
\text { しむ. 停箱根路復足柄路 }\end{array}$ \\
\hline 4 & $\begin{array}{ll}1616 \\
\text { 元和 } 2\end{array}$ & 交通是 & 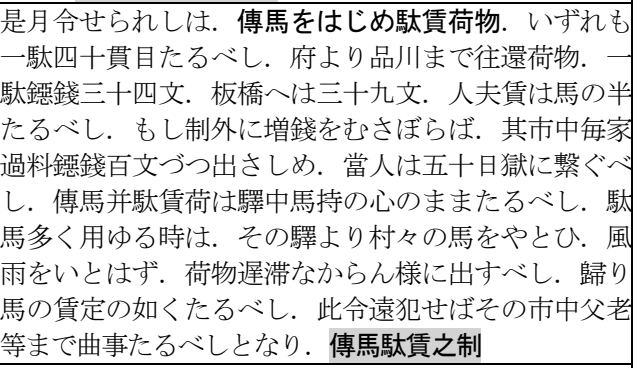 \\
\hline 5 & \begin{tabular}{|c|}
1624 \\
寞永元
\end{tabular} & & $\begin{array}{l}\text { 先手頭一隊づつ年番につとむ. 其制は箱根笛吹兩關に } \\
\text { 准じ. 出入とも券符を照し往來を査撿し. }\end{array}$ \\
\hline 6 & \begin{tabular}{c|c|} 
寞永 2 \\
\end{tabular} & $\begin{array}{l}\text { 維持誩 } \\
\text { 管理湜 } \\
\text { 交通 }\end{array}$ & $\begin{array}{l}\text { 明年御上洛の事を } \\
\text { 梁巡察の事命ぜらる }\end{array}$ \\
\hline 7 & $\begin{array}{c}1628 \\
\text { 寛永5 }\end{array}$ & & $\begin{array}{l}\text { 町奉行へしばしば令せらるる法制類心いれ．卑賤のも } \\
\text { のまで暁諭すべき旨つたぶへし．諸驛道中心を用ひ． } \\
\text { 見聞して聞えあぐべし. }\end{array}$ \\
\hline 8 & \begin{tabular}{c|c} 
寞永 8 \\
\end{tabular} & 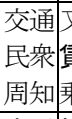 & $\begin{array}{l}\text { 又驛馬の高札を建らる.（中略）府より品川驛まで駄 } \\
\text { 儥銭壹䭾五十文. 乗掛荷は人ともにおなじ. 無荷にて } \\
\text { 烡らば三十二文. 人夫は壹人廿五文たるべしとなり. } \\
\end{array}$ \\
\hline 9 & $\begin{array}{ll}1633 \\
\text { 宽永10 }\end{array}$ & & $\begin{array}{l}\text { 岡. 大目付井上筑後守政重. 柳生但馬守 } \\
\text { 印上洛によて. 各驛御旅館并道路巡察命 } \\
\text { 京. } \\
\text { 巡察上洛各驛旅館道路 }\end{array}$ \\
\hline 10 & \begin{tabular}{|c|} 
寛永11 \\
\end{tabular} & 交通 & 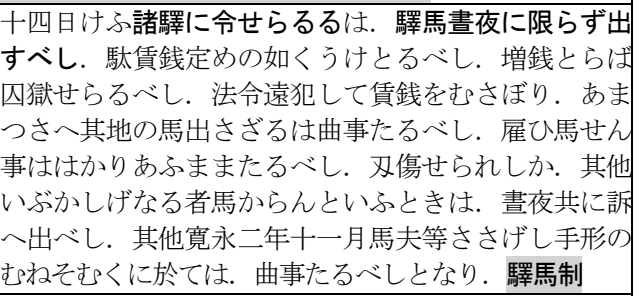 \\
\hline 11 & \begin{tabular}{|c|}
1636 \\
寛永13
\end{tabular} & & $\begin{array}{l}\text { 相模國箱根の關に條約を下さる. その文にいふ. 往來 } \\
\text { の旅人關所前にて笠頭巾脱せしむべし.もし轎にのら } \\
\text { ば戸をひらかせ通すべし. 女乗物は婦女をして改めし } \\
\text { むべし. 公家. 阴跡その他大名. 高家等は. あらかじ } \\
\text { めその沙汰あるべければ査撿に及ばず. 箱根關法度 } \\
\end{array}$ \\
\hline 12 & 呆完 & & $\begin{array}{l}\text { 十六日國廻目付小笠原孫座衛門某. 今福次大夫勝正景 } \\
\text { 坂までの驛路巡察. 大番天野傳左衛門重時. 中根茂助 } \\
\text { 正次は西城大手橋改架奉行命ぜらる. } \\
\end{array}$ \\
\hline 13 & \begin{tabular}{c|c|}
1656 \\
明暦2 \\
\end{tabular} & 交通要 & $\begin{array}{l}\text { また御側所屬の圖目付を東海道の驛路につかはされ. } \\
\text { 毎驛の人馬遅滞すべからざる会せしめら. }\end{array}$ \\
\hline 14 & $\begin{array}{ll}1660 \\
\text { 万治 } 3 \\
\end{array}$ & & $\begin{array}{l}\text { 諸驛に令せらるるは．高札の旨． 其他令制遠犯のもの } \\
\text { あらば. 各驛の役人． 宿驛制度 }\end{array}$ \\
\hline 15 & \begin{tabular}{|c|}
1662 \\
寞文 2 \\
\end{tabular} & & Dさま巡察ぜられ \\
\hline 16 & \begin{tabular}{c|c|c|} 
寛文3 \\
\end{tabular} & & $\begin{array}{l}\text { 道路. 驛馬. 舟梁等無断絶. 不可令往還 } \\
\text { 之關所. 新法之津留制禁之事. 武家諸法度 }\end{array}$ \\
\hline 17 & \begin{tabular}{|c|}
1664 \\
寞文 4
\end{tabular} & 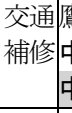 & $\begin{array}{l}\text { 鷹司家の姫君参向により．大番組頭小川新九郎安則. } \\
\text { 中山道驛々橋梁修治并に扈從の事仰付らる. } \\
\text { 中山道諸驛及橋梁修治 }\end{array}$ \\
\hline 18 & \begin{tabular}{|c|}
1664 \\
寞文4
\end{tabular} & & 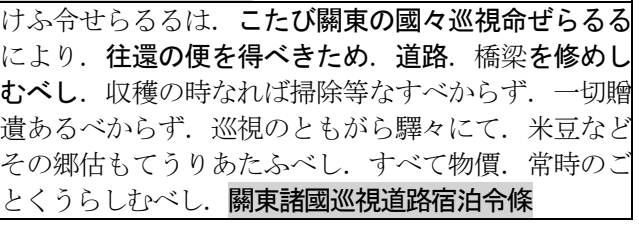 \\
\hline
\end{tabular}

表-9『徳川実紀』にみる「流通・交通政策」

\begin{tabular}{|c|c|c|c|c|}
\hline NNo. & 西暦 & 和暦 & 記載事項 \\
(斜線部は『德川実紀』に記載の脚注)
\end{tabular}

191665 交通また中山道諸驛に令せらるるは. 人馬書夜風雨のとき 寛文5 も。とどこほらず出すべし．毎驛に馬五十疋を備へ。 大名一家に一日に二十五疋出すべきむ㸚。ささきに令せ られぬ。.ゆききのともがちにその旨を告て．定外に出 すべからず．驛夫もこれにおなじ．轎は六人の價うく ベし．山轎は四人の價たるべし．負擔は一夫五貫目を かぎるべし，長持は十貫目は二人。二十貫目は四人。 三十貫目は六人．それよりおもきは搬送すべからず． 一馬五貫目迄の荷物は．から尻とおなじ價をうくべ し．それよりおもきは．本馬の定價をうくべし．夜中 はからじりも本馬に同じ．本馬二割増の價をうくる事 は.あらかじめ令すべし，薪價うにて投宿するもまた おなじ．すべて驛々にて道中奉行の家士と稱するもの あらば.とらへ置うたへ出べし. 奉行の家士ならば. 其主人より死刑に處すべし．もし他人のいつはり稱す るものは. 官よりきびしく罰せらるべければ。 その心 してうたへ出べし．東海道とおなじく，娼婦．博戯の 事. いよいよかたく禁ぜられ. 五人組の印記をとり置 べきむね，庄屋．問屋に令すべしとなり。

\section{中山道宿驛制}

201665 交通けふ品川．板橋．千住の驛に．あらためて高札を建て 寛文 5 周知 らる. 品川板橋千住驛高札

211666 交通中山道諸驛高札改らるるによて歩行目付つかはさる. 寞文6 周知中山道諸驛高札

221666 交通この月令せらるるは．驛路に高札を立らる．近年米豆 寛文6 周知の價湧貴するをもて．驛々難困するにより．鳩が谷よ

り大門へ駄賃銭一駄に五十文.乗掛荷は人ともに上に 同じ。荷なくて乗るは三十三文．夫は二十五文．川口 一一駄四十三文．荷なきは二十九文．夫は二十一文と るべし．ゆききのともがら近年人馬を多く用るをも

て。驛々難困すれば．たとひ國持大名たりといふと も。家士ともに一日二十五匹. 二十五人に過べから ず．此外に人馬用ひば．その日の前後にわかちて用ゆ ベし．人馬ともに定のごとく．驛々にてつぎ立べし． もし追ひ通すものあらば.（以下略）

遣使巡察東海東山堤防破壊地

231667 交通十六日奥州白川まで．諸驛高札建政のため歩行目付遣 寛文7 周知はさる. 諸驛高札改建

241674 交通此月各驛に銭を恩貸せらる. 東海道は品川より枚方に 延宝2 いたる六十六驛のうち．五十五驛は毎驛各千貫文．由 比は三千貫文，橋本，守口の二驛は各四百貫文．六 郷. 馬入. 富士. 天龍. 熱田. 桑名の六津もおなじ。 安部。大井の川越夫は各百貫文．中山道下板橋より守 山に至る七十九驛は各三百五十貫文. 日光井に奥道千 住より白川に至る四十四驛のうち三十八驛は各三百五 十貫文. (以下略) 府下傳馬町及五街道宿驛恩貸

251675 交通廿七日東海. 木曾兩驛道艱困のさまを. 歩行者付二人 延宝3 して巡察せしめらる. 人馬賃銭増加ある故とぞ. 東海木曾兩驛道艱困

261686 職掌此月道中奉行して令せられしは. 驛次往来のもの. 荷 貞享3 交通物の貫目定限より。近年は重きも有りて。人馬とも其 數を增し．驛々艱困するよしなれば．定制貫目より重 からしむべからずとなり．驛路制

271690 交通此月令せらるるは．近年諸驛鞎困するにより．こたひ 元禄3 人馬駄賃銭. 東海道は一割半. 其他は一割增たる

し. 中山道. 日光道中. 甲州奥州道中. 美濃佐屋路. 水戸佐倉道中にも此旨令せらる. 又馬入川．天龍川． 富士川も添高札建られ. 其條約を載らる.

諸驛駄賃增加

281698 交通少老米倉丹後守昌尹京攝河功. 東海驛路巡察の事命せ 元禄11 維持らる.

管理

291698 職掌七日勘定奉行松平美濃守重良. 大目付神尾備前守元清 元禄11交通と共に. 驛路の事奉るべしと仰付らる. 
表-10 『徳川実紀』にみる「流通・交通政策」

$(3 / 4)$

\begin{tabular}{|c|c|c|c|}
\hline No. & \begin{tabular}{|l|l} 
西暦 \\
和暦 \\
\end{tabular} & 項目 & $\begin{array}{c}\text { 記載事項 } \\
\text { (斜線部は『徳川実紀』に記載の脚注) } \\
\end{array}$ \\
\hline 30 & \begin{tabular}{|c|}
1704 \\
宝永元
\end{tabular} & & 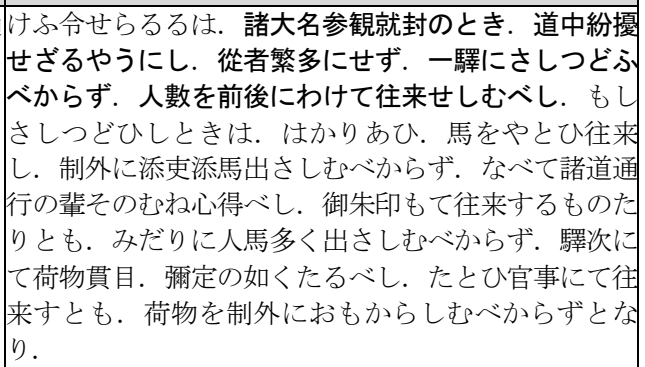 \\
\hline 31 & \begin{tabular}{|c|}
1705 \\
宝永2 \\
\end{tabular} & & $\begin{array}{l}\text { 七日勘定奉行石尾阿波守氏信驛路の事令ぜらる. } \\
\text { 勘定奉行石尾氏信掌驛路事 }\end{array}$ \\
\hline 32 & \begin{tabular}{|c|}
1707 \\
宝永4
\end{tabular} & & $\begin{array}{l}\text {. 本多吉十郎忠孝. 眞田伊豆 } \\
\text { を命ぜらる. 諸驛修築助役 }\end{array}$ \\
\hline 33 & \begin{tabular}{|c|}
1709 \\
宝永6
\end{tabular} & $\begin{array}{l}\text { 交通 } \\
\text { 禁止 } \\
\text { 事項 }\end{array}$ & $\begin{array}{l}\text { また令せられしは. 牛馬あまたひきつづき. 往来のさ } \\
\text { またげすべからざる旨. しばしば令すといへども. 頃 } \\
\text { 日また猥りなるよし聞ゆ. さあらむには. 此後牛引者 } \\
\text { はさらなり. 其主并に其地の父老までも. 嚴料に處せ } \\
\text { はるべしとなり. }\end{array}$ \\
\hline 34 & \begin{tabular}{|c|}
1711 \\
正徳元
\end{tabular} & 交通 & 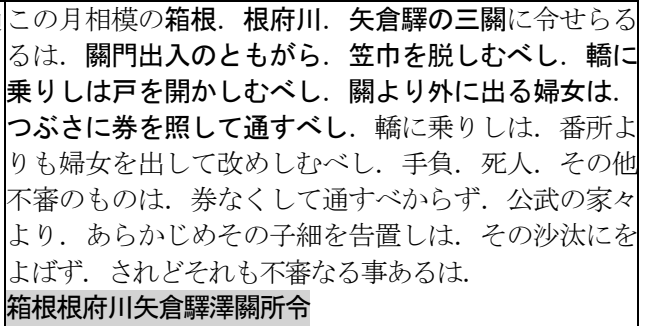 \\
\hline 35 & \begin{tabular}{|c|}
1711 \\
正徳元
\end{tabular} & 交通 & 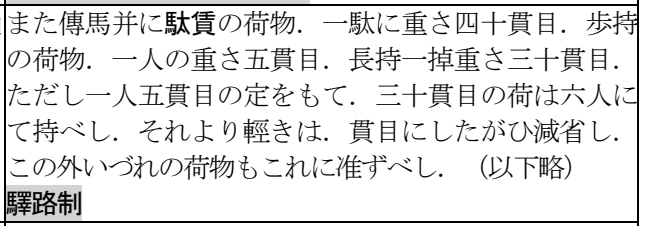 \\
\hline \begin{tabular}{|l|}
36 \\
\end{tabular} & 苗元 & $\begin{array}{l}\text { 交通 } \\
\text { 維持 } \\
\text { 管理 }\end{array}$ & 乗邦驛路巡察はてて歸謁す。勘今 \\
\hline 37 & \begin{tabular}{|c|}
1712 \\
正徳 2
\end{tabular} & 交通 & 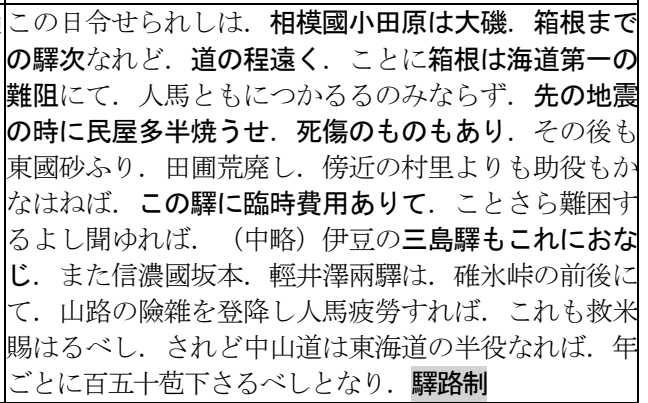 \\
\hline \begin{tabular}{|l|}
38 \\
\end{tabular} & 呆6 & & 磨守重賢驛路の事奉はる. \\
\hline 39 & \begin{tabular}{|c|}
1724 \\
享保 9 \\
\end{tabular} & 職掌 & 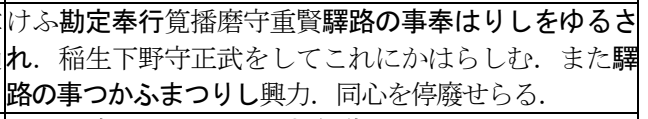 \\
\hline 40 & $\begin{array}{c}1725 \\
\text { 享保10 }\end{array}$ & 交通 & 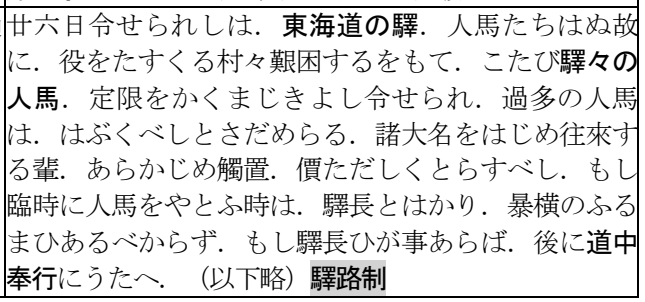 \\
\hline
\end{tabular}

表-11『徳川実紀』にみる「流通・交通政策」

$(4 / 4)$

\begin{tabular}{|c|c|c|c|}
\hline Vo. & \begin{tabular}{|l|l|} 
暦 \\
暦
\end{tabular} & 日 & $\begin{array}{c}\text { 記載事項 } \\
\text { （斜線部は『徳川実紀』に記載の脚注） }\end{array}$ \\
\hline 41 & $\begin{array}{l}37 \\
\text { 文2 }\end{array}$ & \begin{tabular}{|l} 
交通 \\
改良
\end{tabular} & 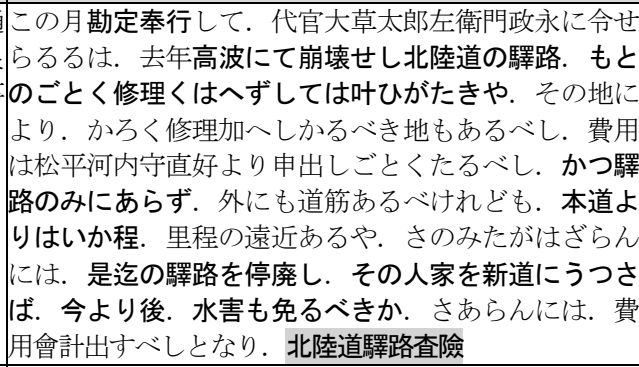 \\
\hline 42 & \begin{tabular}{|c|}
1742 \\
寛保2 \\
\end{tabular} & 交通 & 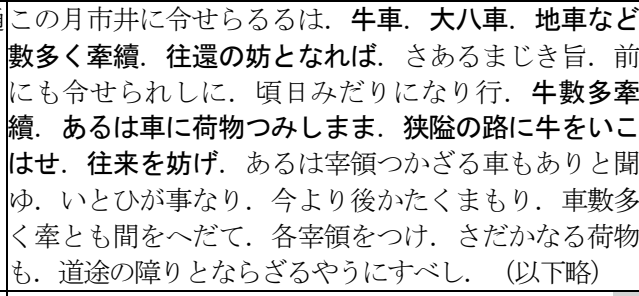 \\
\hline 3 & \begin{tabular}{|c|}
1747 \\
延享4
\end{tabular} & & 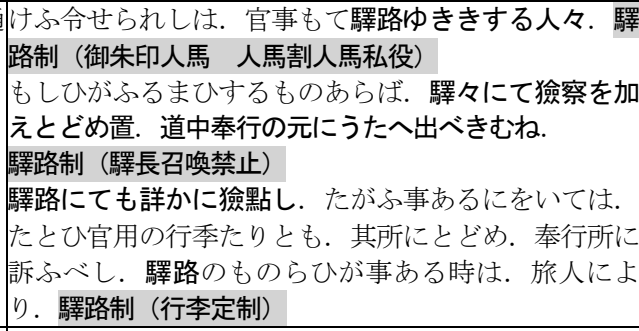 \\
\hline 44 & \begin{tabular}{|c|}
1758 \\
宝暦8
\end{tabular} & 交通 & $\begin{array}{l}\text { 八日諸道旅行の制度を定め令せらる. 公用もて旅行の } \\
\text { ともがら. 御朱印の券にしるされし定額の外に. 人馬 } \\
\text { 多くいださしむるよし聞ゆ. さきざきも令せられし如 } \\
\text { く. 限外の人馬かたく出さしむべらず. 定額の外の } \\
\text { 人馬は. 賃銭定のごとく興ふべし. (以下略) 驛路制 }\end{array}$ \\
\hline$\overline{5}$ & \begin{tabular}{|c|}
1758 \\
宝暦8
\end{tabular} & & 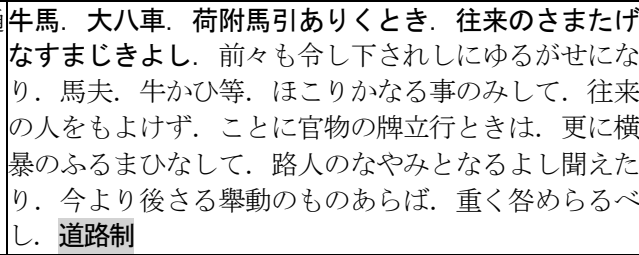 \\
\hline
\end{tabular}

はさらなり，其主并に其地の父老までも，嚴料に處せ らるべしとなり。

道路上では牛や馬だけではなく，牛車や大八車などの今 でいう違法駐車が増えたため，それらが往来の妨げにな らないようにせよと示されていた（表-11 No.42）。

\section{d) 関所における通行の取り締まり}

関所を通行する際，その取り締まりの内容について詳 述した記載が存在した．寛永元（1624）年（表-8 No.5）, 「先手頭一隊づつ年番につとむ. 其制は箱根笛吹兩關に 准じ．出入とも券符を照し往來を査撿し．」 箱根と笛吹の関所を出入り寸る人々に対して，通行許可 を持っているか，その確認をするよう命じた.

正徳元（1711）年（表-10 No.34）には,

「この月相模の箱根．根府川．矢倉驛の三關に令せらる るは，關門出入のともがら，笠巾を脱しむべし，轎に 乗りしは戸を開かしむべし．關より外に出る婦女は. つぶさに券を照して通すべし．轎に乗りしは．番所よ 
りも婦女を出して改めしむべし．手負．死人．その他 不審のものは. 券なくして通す心゙からず，公武の家々 より。あらかじめその子細を告置しは. その沙汰にを よばず。されどそれも不審なる事あるは.」

相模国の箱根, 根府川, 矢倉を通過する際の取り締まり に関する記述であった，そして，婦女が先の関所を超え る場合, 被っている笠は脱がすこと, 籠に乗っている場 合は扉を開けたうえで，速やかに通行許可を照合するよ う要請がなされた。朝廷や幕府からの事前告知があった 場合を除いて, 通行許可を持っていない負傷者, 死者, その他の不審者, 不審物を通行させないよう, 命令が下 されていた．これは，いわゆる「入り鉄砲に出女」を指 すと考えられ，『日本国語大辞典』39をみると，

「江戸時代，関所を越えて，江戸に持ち込まれる鉄砲と， 江戸から地方に出る江戸在住の婦女子のこと．鉄砲は 謀反などに利用されるのを防ぐため，婦女子は人質と して江戸居住させられている大名の妻が変装して江戸 を脱出するのを防ぐために，関八州の関所，ことに上 方に通じる箱根できびしく詮議した。」

とあり, 関所での厳しい取り締まりが実施されていた.

\section{(5) 禁止事項}

道路管理者が，道路使用者の勝手な占有等を禁ずる規 則を制定したものである. 本研究で対象とした『徳川実 紀』には，8 ケ所にその記載があった.

慶長 12（1607）年（表-12No.1）,

「十九日道路の制を令せらる. 堤と河邊との間に。牛馬 を放ちかふ心゙からず。道の外をみだりに往還すべから ず、樹木接木等に差さはるべからず．此令にそむくも のは. 曲事たるべしとなり。」

牛や馬などの家畜を堤防法面や堤外地での放牧，堤防の 道路ではない部分（天端部分を指寸力）をみだりに往来 させることを禁止していた。 これは，堤防法面が崩壊し ないよう保護すると共に, 河川の流路を無計画に変化さ せない目的があったと考えられる。また, 慶長 16

（1611）年にも，ほぼ同様の記述が再度掲載されていた (表-12No.2) .

寬文 8 （1668）年の『器財道路埋没禁制』では（表-12 No.7) ,

「市井大路をほりて，諸器財を埋をくにより道せばく． ゆききのささはりとなれば. 今よりのち大路に器財を 埋むべからず，埋置しは寸みやかにほり出し，道を修 築すべし，もしそむかば嚴にとがめらるべし，かまへ ていささかも急るべからずとなり。

大路を掘削して, 家財道具等を埋めたために, 道路の幅 員が狭くなり，往来の妨げとなっていた．速やかに埋め たものを取り出し, 元の状態へ戻すよう定められた.

\section{(6) 民衆への周知}

民衆一周知を図る目的で設置した高札に関するものが 8 項目で記載されていた，高札とは，『大辞泉』37によ ると，

「主に江戸時代，法度・禁令，犯罪人の罪状などを記し， 一般に告示寸るために町辻や広場などに高く掲げた板

の札。明治 6 年（1873）廃止．たかふだ。」 を指す。

\section{a) 高札の設置}

高札の設置は，その記載内容の更新や変更を実施した と記載されていた．寛文 5（1665）年（表-13No.3）,

「中山道諸驛高札改らるるによて歩行目付つかはさる.」 「けふ. 品川. 板橋. 千住の驛に. あらためて高札を建 らる.」

翌年の寛文 6 （1666）年（表-13No.4およびNo.5）,

表-12 『徳川実紀』にみる「禁止事項」の項目

\begin{tabular}{|c|c|c|c|}
\hline Vo. & 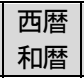 & 目目 & $\begin{array}{c}\text { 記載事項 } \\
\text { （斜線部は『徳川実紀』に記載の脚注） }\end{array}$ \\
\hline 1 & $\begin{array}{ll}1607 \\
160\end{array}$ & 禁止 & 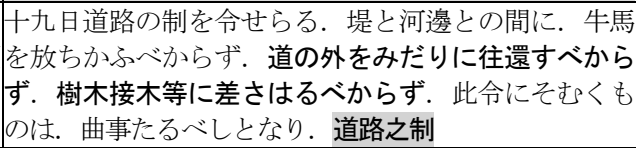 \\
\hline 2 & \begin{tabular}{|c|}
1611 \\
慶長16
\end{tabular} & \begin{tabular}{|l|} 
禁止 \\
事項
\end{tabular} & $\begin{array}{l}\text { この日道路の法令を仰下さる. 堤と川よけの間に牛馬 } \\
\text { を放へからず．道路ならぬ所をみだりに行来すべから } \\
\text { ず. 樹木ならびにさし木等にさはるべからずとなり. } \\
\text { 道路法度 }\end{array}$ \\
\hline 3 & $\begin{array}{ll}1612 \\
1617\end{array}$ & 維持 & 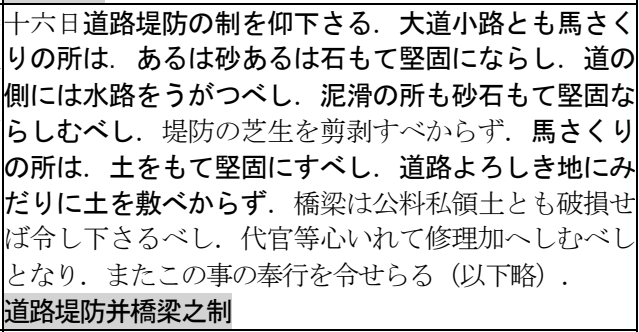 \\
\hline 4 & & 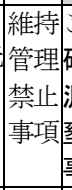 & 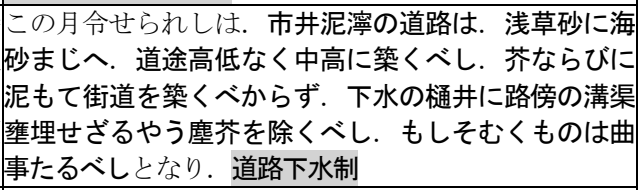 \\
\hline 5 & \begin{tabular}{|c|}
1657 \\
明暦3
\end{tabular} & $\begin{array}{l}\text { 維持 } \\
\text { 管理 } \\
\text { 禁止 } \\
\text { 事項 }\end{array}$ & 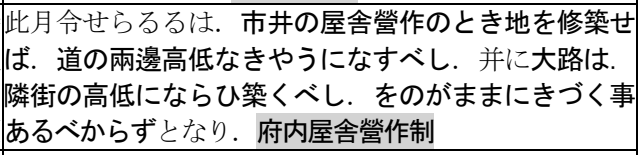 \\
\hline 6 & \begin{tabular}{c|c|}
1659 \\
万治 2
\end{tabular} & $\begin{array}{l}\text { 維持 } \\
\text { 管理 } \\
\text { 禁止 } \\
\text { 事項 }\end{array}$ & 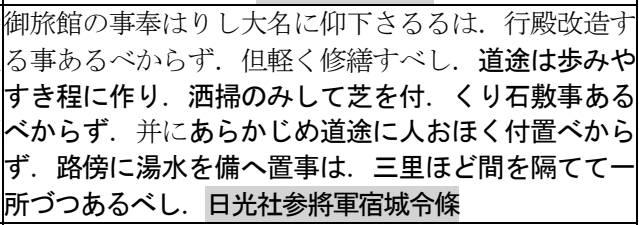 \\
\hline 7 & \begin{tabular}{|c|}
1668 \\
寛文 8 \\
\end{tabular} & & 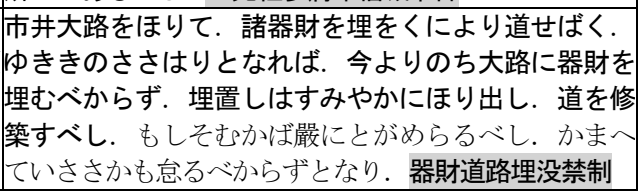 \\
\hline 8 & \begin{tabular}{|c|}
1709 \\
宝永6 \\
\end{tabular} & $\begin{array}{l}\text { 交通 } \\
\text { 禁止 } \\
\text { 事项 }\end{array}$ & $\begin{array}{l}\text { また令せられしは. 牛馬あまたひきつづき. 往来のさ } \\
\text { またげすべからざる旨. しばしば令すといへども. 頃 } \\
\text { 日また猥りなるよし聞ゆ. さあらむには. 此後牛引者 } \\
\text { はさらなり. 其主并に其地の父老までも. 嚴料に處せ }\end{array}$ \\
\hline
\end{tabular}


「この月令せらるるは．驛路に高札を立らる．近年米豆 の價湧貴するをもて．驛々難困するにより．」

主として，高札をいつ，どこに立てたか，また高札の改 正を中心に記述がなされていた.

\section{b) 高札の施工手法}

海岸沿いに設置した高札の施工手法を記述したものが 1 ケ所でみられた。寛文 8（1668）年（表-13No.7）,

「又令せらるるは. 各浦高札. これより先は上品の木材 を用ゆるといいども。こたびは雑木を用べし．其地處 は野づら石垣もて築き。もし石にて便りよからぬ地は。 芝土居たるべし，其地にありあふ木もて雨覆をすべし 年月を經て. 札の文字見えわかざるに至らば. 地頭. 代官のもとにうたへ．私領は地頭より改め建べし．公 料は代官より．勘定頭に伺ひて指揮を得べしななり。」 今後，高札には質の良い木材を用いること，その基礎に は野面積夕で石垣を築き，石垣で不安な場合には，芝土 居（土をつき固めた表面に芝を張ったもの）とすること， その土地にある木材で良いから，高札に書かれた内容を 降雨から守る覆いを付けることとしている，そして，時 間を経て札の文字が見えづらくなった場合には地頭，代 官の元へ訴えることと示されていた，海浜部では，その 他の設置場所と比較して, 高札の倒壊や文字の消失が頻 繁に生じていたと思われる。

\section{5. 道路施工}

本章では，道路造成や補修などの具体的な事業につい てまとめた。「道路施工」は，前章で示した「規則の制 定」の 120 項目よりも非常に少ない 25 項目であった.

\section{(1) 新規造成}

本研究で対象とした時代に，「道路」の新規造成を行 ったとする記述は，4 項目と少ない状況にあった.

\section{a) 築城に付随する道路造成}

築城に付随するとみられる工事が 2 ケ所でみられた. 元和元（1615）年（表-14 No.1）,

「かの城溝悉く埋終り。二三丸の掘門櫓残る所なく破却

し. 本城櫻門邊を往来の道路とするよし聞え上る．」 城溝（堀力）を埋めて往来する道路を造成した。 そして, 万治元（1658）年（表-14No.3）には，

「三丸兩所搆造の時. 石を持運ぶ人夫通路のため. 新道 を開き番舎をいとなみ，警衛すべしと仰付らる。」

三の丸を築城する際，石を運搬する人夫のために道路を 開削したとみられる。

\section{b) 社会基盤としての道路造成}

人々が日常生活で使用する「道路」の造成は，2 ケ所 に記述があり，寛文 2（1662）年（表-14No.4），
「晦日五番町より二番町まで直路を開かるるにより。そ のほとり居住の御家人三人轉宅せしめらる. よて各引 料二百兩づつ下さる.

まっすぐな線形を持つ道路を計画したため，その区間と 重なる宅地の移転費用が御家人三人へ支払われたとみら れる。このように，民衆が使用する社会基盤としての 「道路」を新規に造成したものは，先述の表-14 No.3 と 表-14 No.2 を含めて 2 ヶ所の記載にとどまっていた.

表-13『徳川実紀』にみる「民衆への周知」の項目

\begin{tabular}{|c|c|c|c|}
\hline No. & 西暦 & 須目 & (斜線部は『事項川実紀』に記載の脚注)
\end{tabular}

11631 交通又驛馬の高札を建らる. 其文にいふ. （中略）府より 寛永8 民衆品川驛まで駄賃銭壹駄五十文．乗掛荷は人ともにおな 周知じ．無荷にて乗らば三十二文．人夫は壹人廿五文たる ベしとなり

21660 交通諸驛に令せらるるは．高札の旨．其他令制遠犯のもの 万治3 周知あらば. 各驛の役人. 宿驛制度

3 3665 交通けふ品川．板橋．千住の驛に．あらためて高札を建て 寛文5 周知 らる. 品川板橋千住驛高札

41666 交通中山道諸驛高札改らるるによて歩行目付つかはさる. 宽文6 周知中山道諸驛高札

5 1666 交通この月令せらるるは．驛路に高札を立らる．近年米豆 寛文6 周知の價湧貴するをもて．驛々難困するにより．鳩が谷よ り大門へ駄賃銭一駄に五十文. 乗掛荷は人ともに上に 同じ．荷なくて乗るは三十三文．夫は二十五文．川口 一一駄四十三文．荷なきは二十九文．夫は二十一文と るべし、ゆききのともがら近年人馬を多く用るをも

て。驛々難困すれば．たとひ國持大名たりといふと も．家士ともに一日二十五匹．二十五人に過べから ず．此外に人馬用ひば，その日の前後にわかちて用ゆ ベし. 人馬ともに定のごとく．驛々にてつぎ立べし． もし追ひ通すものあらば.（以下略） 遣使巡察東海東山堤防破壊地

61667 交通十六日奥州白川まで．諸驛高札建政のため歩行目付遣 寛文7 周知はさる. 諸驛高札改建

71668 周知又令せらるるは. 各浦高札. これより先は上品の木材 寞文8 を用ゆるといいども。こたびは雑木を用べし．其地處 は野づら石垣もて築き．もし石にて便りよからぬ地 は. 芝土居たるべし. 其地にありあふ木もて雨覆をす ベし．年月を經て． 札の文字見えわかざるに至らば. 地頭. 代官のもとにうたへ、私領は地頭より改め建心 し. 公料は代官より。勘定頭に伺ひて指揮を得べしと なり. 各浦高札制

81692 周知この月軽井澤驛または和田驛．下諏訪驛道路險盆に

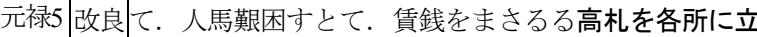
工事らる．また野尻驛．原驛の間險阻により．新に道を改 造し．行程六町餘延たればとて。これも人馬の增銭女 り。宿驛制

91721 周知日本橋に高札を建らる. その文にいふ. 近き此幾度と 享保6 なく. 所々に名もなき捨文して.ささまざまの事申寸者 あり. 日本橋高札（目安箱設置）

表-14 『徳川実紀』にみる「新規造成」の項目

\begin{tabular}{|c|c|c|c|}
\hline 10. & $\begin{array}{l}\text { 西暦 } \\
\text { 和暦 }\end{array}$ & 項目 & $\begin{array}{c}\text { 記載事項 } \\
\text { (斜線部は『徳川実紀』に記載の脚注) }\end{array}$ \\
\hline 1 & \begin{tabular}{c|c|}
1615 \\
元和元
\end{tabular} & & $\begin{array}{l}\text { かの城溝悉く埋終り。二三丸の掘門櫓残る } \\
\text { し. 本城櫻門邊を往来の道路とするよし聞え }\end{array}$ \\
\hline 2 & $\begin{array}{l}1620 \\
\text { 元和6 }\end{array}$ & & $\begin{array}{l}\text { 广ふ 女御入内し給ふ. か才 } \\
\text { 道作り。 }\end{array}$ \\
\hline 3 & $\begin{array}{c}1658 \\
\text { 万治元 }\end{array}$ & 新規 & $\begin{array}{l}\text { 時. 石を持運ぶ人夫通路のため. 新通 } \\
\text { となみ. 警衛すべしと仰付らる. }\end{array}$ \\
\hline 4 & $\begin{array}{c}1662 \\
\text { 寛文2 }\end{array}$ & & $\begin{array}{l}\text { 二番町まで直路を開かるるにより．そ } \\
\text { 御家人三人轉宅せしめらる. よて各引 } \\
\text { さる. 法度（塵芥） }\end{array}$ \\
\hline
\end{tabular}




\section{（2）改良工事}

既存の道路幅員を拡張したり，代替となる「道路」を 建設したりしていたことが 6 項目で示されていた．天正 10（1582）年（表-15No.1）,

「さて右府國中の刑賞悉く沙汰しはてて．かへさに駿河 路をへて富士一覽あるべしとの事なり。そのあたりは 君しろしめす所なるがゆへに，其道すがらの大石をの け，大木をきりはらひ道橋をおさめられ。」

富士山を一望できる所は領主が管理するため, 大石を取 り除き，大木を切り倒して，そこまでの「道路」や橋梁 を設置したとみられる.

寛永 18（1641）年（表-15No.3）,

「安國殿を塔の方に引うつされ。塔をば又其傍にうつし. 本坊よりつづきし楼閣. 山門の傍の僧坊を破壊し. 道 をひろくなさるべきよしなり。」

安國殿は増上寺にあり, 本記述は伽藍内の配置変更であ ったとみられ, 本研究で対象とした社会基盤としての 「道路」には該当しないと考えられる。

元禄 5（1692）年（表-15No.4）には,

「この月軽井澤驛または和田驛。下諏訪驛道路險险にて。 人馬艱困すとて．賃銭をまさるる高札を各所に立らる. また野尻驛。原驛の間險阻により，新に道を改造し．

行程六町餘延たればとて。これも人馬の增銭あり。」

野尻驛と原驛の間が険阻で，人や馬の往来に支障をきた していた，そこで，路線を六町（約 $654.5 \mathrm{~m}$ ）余延長し て，勾配が緩やかな道路へと改良した，それに伴い，通 行料の值上げが行われたとみられる。

道路の付け替え工事としては，明暦元（1655）年に品 川芝浦の海辺を通る道路の記述があり（表-16No.6），

「品川芝浦海濱の道路を修治せしめらるる」

波の浸食で道路が削られ，その補修が行われた。 それか ら，80 年余後の享保 19 （1734）年（表-15No.5）には,

「品川驛并に大森村の海邊營築の事. 先年よりしばしば 修理せしめられしが。久しく保がたし．よてこたび商 議のうへ. 山手の方に往還をうつしかへしむべけれ ば.」

長年にわたり道路を修理してきたものの，それ自体が困 難となり，山手一道路を移動させた．品川周辺の道路修 築に関して，『徳川実紀』には，これら 2 項目にとどま っていたが，補修は頻繁に実施されていたと思われる. 道路の付け替えは，元文2（1737）年（表-15 No.6）に も行われ，

「この月勘定奉行して. 代官大草太郎左衛門政永に令せ らるるは．去年高波にて崩壊せし北陸道の驛路. もと のごとく修理くはへずしては叶ひがたきや，その地に より．かろく修理加へしかるべき地もあるべし．費用 は松平河内守直好より申出しごとくたるべし. かつ驛 路のみにあらず，外にも道筋あるべけれども，本道よ
表-15『徳川実紀』にみる「改良工事」の項目

\begin{tabular}{|c|c|c|c|}
\hline No. & \begin{tabular}{|l|} 
西暦 \\
和暦 \\
\end{tabular} & 項目 & $\begin{array}{c}\text { 記載事項 } \\
\text { (斜線部は『徳川実紀』に記載の }\end{array}$ \\
\hline 1 & $\begin{array}{ll}1582 \\
\text { 天正10 }\end{array}$ & 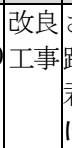 & $\begin{array}{l}\text { さて右府國中の刑賞悉く沙汰しはてて. かへさに駿河 } \\
\text { 路をへて富士一覽あるべしとの事なり．そのあたりは } \\
\text { 君しろしめす所なるがゆへに. 其道すがらの大石をの } \\
\text { け. 大木をきりはらひ道橋をおさめられ. }\end{array}$ \\
\hline 2 & $\begin{array}{ll}1614 \\
19\end{array}$ & & $\begin{array}{l}\text { またこのころ箱根路の往還を停廢し. 足柄路を通行せ } \\
\text { しむ. 停箱根路復足柄路 }\end{array}$ \\
\hline 3 & \begin{tabular}{|c|}
1641 \\
寛永18
\end{tabular} & 改良 & $\begin{array}{l}\text { 安國殿を塔の方に引うつされ．塔をば又其傍にうつ } \\
\text { L. 本坊よりつづきし廊閣. 山門の傍の僧坊を破壊 } \\
\text { L. 道をひろくなさるべきよしなり. } \\
\text { 増上寺安國殿移転 }\end{array}$ \\
\hline 4 & \begin{tabular}{|l|}
1692 \\
元禄5
\end{tabular} & 周知 & 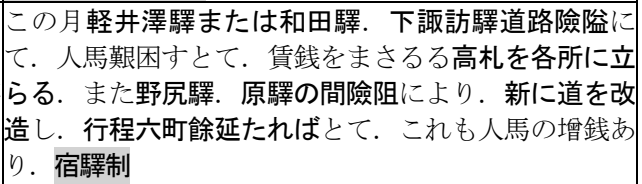 \\
\hline 5 & $\begin{array}{c}\text { 享保19 } \\
1734\end{array}$ & & $\begin{array}{l}\text { 品川驛并に大森村の海邊營築の事. 先年よりしばしば } \\
\text { 修理せしめられしが. 久しく保がたし. よてこたび商 } \\
\text { 議のうへ. 山手の方に往還をうつしかへしむべけれ } \\
\text { ば. 品川驛并大森海邊營築 }\end{array}$ \\
\hline 6 & \begin{tabular}{|c|}
1737 \\
元文2
\end{tabular} & \begin{tabular}{l|} 
交通 \\
改良 \\
工事
\end{tabular} & $\begin{array}{l}\text { この月勘定奉行して. 代官大草太郎左衛門政永に令せ } \\
\text { らるるは. 去年高波にこて崩壊せし北陸道の驛路. もと } \\
\text { のごとく修理くはへずしては叶ひがたきや. その地に } \\
\text { より. かろく修理加へしかるべき地もあるべし. 費用 } \\
\text { は松平河内守直好より申出しごとくたるべし. かつ驛 } \\
\text { 路のみにあらず. 外にも道筋あるべけれども. 本道よ } \\
\text { りはいか程. 里程の遠近あるや. さのみたがはざらん } \\
\text { には. 是迄の驛路を停廃し. その人家を新道にうつさ } \\
\text { ば. 今より後. 水害も免るべきか. さあらんには. 費 } \\
\text { 用會計出すべしとなり. 北陸道驛路査險 }\end{array}$ \\
\hline
\end{tabular}

りはいか程. 里程の遠近あるや.さのみたがはざらん には．是迄の驛路を停廢し，その人家を新道にうつさ ば．今より後．水害も免流べきか，さあらんには．費 用會計出す心゙しとなり。」

北陸道の驛が高波で崩壊したため, 従来の驛を廃止し， 新道を沿線に付け替えた．この対策を実施した事で，水 害をうけることも免れるようになるのではないかと記さ れていた．なお，本事業は「普請奉行」でなく「勘定奉 行」が代官へ命じて改良工事を実施していた.

\section{（3）補修（災害復旧を含む）}

災害復旧を含む道路の維持管理や補修に関する具体的 な事例として，15 項目が該当した。既存の道路を維持 管理していく必要があったと考えられ，掲載年の偏りは みられなかった。

\section{a) 日光街道の補修}

徳川家康を祀る日光山一至る日光街道の修理は 3 ヶ所 に記述があった．寛永元（1624）年（表-16No.1），

「廿一日此日日光山御宮造營により。惣奉行命ぜられし 松平右衛門大夫正綱. 秋元但馬守泰朝に. 老臣連署の 令を下さるる府より日光山に往来の諸驛道橋修理.」 日光東照宮を造営するため, 日光街道の宿場や橋梁に加 え，「道路」の修理が行われた。 それ以後の寛文 3 （1663）年（表-17 No.9）には, 
「こたび日光山に詣たまふ道の事。神田橋門より本郷を 御経過あれば. とほらせ給ふ市井．わけて心を入洒掃 すべし，道路あしき地は一兩日をかぎり。浅草砂もて 中たかく修築すべし.」

日光街道の神田橋より本郷の間で，掃除および道路事情 が悪い部分の補修を行っていた。

\section{b) 中山道および木曽路の補修}

日光街道と同様，五街道の一つに数えられる中山道に ついて，3 ケ所で道路の修理に関する記述があった。

寛永 11（1634）年（表-16No.3）には,

「九日御上洛供奉の輩. 木曽路通行すべきをもて．道梁 修理加ふべし.」

そして，寛文 4（1664）年には中山道の記述が表-17 No.10で再びみられ，

「中山道驛々橋梁修治并に扈從の事仰付らる.」

表-16『徳川実紀』に記載された「補修」の項目（1/2)

\begin{tabular}{|c|c|c|c|}
\hline No. & $\begin{array}{l}\text { 西暦 } \\
\text { 和暦 }\end{array}$ & 項目 & $\begin{array}{c}\text { 記載事項 } \\
\text { (斜線部は『徳川実紀』に記載の脚注) }\end{array}$ \\
\hline 1 & 1624 & & $\begin{array}{l}\text { 廿一日此日日光山御宮造營により. 惣奉行命ぜられし } \\
\text { 松平右衛門大夫正綱. 秋元但馬守泰朝に. 老臣連署の } \\
\text { 令を下さるるは. 府より日光山に往来の諸驛道橋修 } \\
\text { 理. 日光山造營法度一 }\end{array}$ \\
\hline 2 & \begin{tabular}{|c|c|} 
寛永 1033 \\
\end{tabular} & & $\begin{array}{l}\text { 今曉關東大地震す. こと更相州小田原一驛ことごとく } \\
\text { 破潰し. 民室一ものこらず. 泥水湧出. 箱根山より } \\
\text { 岩石くづれて落て. 行人これがためにうたれ）死する } \\
\text { もの多かりしとぞ. よて稲葉丹後守正勝に. 速に道路 } \\
\text { の修治を加ふべしと命ぜらる. } \\
\text { 関東大地震小田原驛全滅 }\end{array}$ \\
\hline 3 & \begin{tabular}{|l|l} 
寛永 11 \\
\end{tabular} & & $\begin{array}{l}\text { 九日御上洛供奉の輩. 木曽路通行すべきをもて．道梁 } \\
\text { 修理加ふベし. }\end{array}$ \\
\hline 4 & $\begin{array}{l}1649 \\
\text { 慶安2 }\end{array}$ & & $\begin{array}{l}\text { 又市井に令せらるるは. こたび大納言殿日光御詣によ } \\
\text { り.御経過の道路は. みな廣さ一間半通りに海砂をし } \\
\text { き. 兩脇にある家の前には浅草砂をしくべし.（中 } \\
\text { 略）市街の兩端. 浅草砂少しづつ敷べし.もし路せば } \\
\text { き所はこの事に及及゙ずとなり. 家綱日光社参道中法度 }\end{array}$ \\
\hline 5 & $\begin{array}{c}1655 \\
\text { 明暦元 }\end{array}$ & & 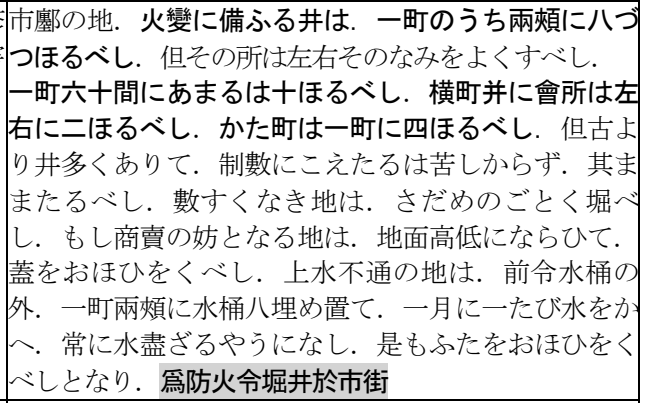 \\
\hline 6 & $\begin{array}{c}1655 \\
\text { 明暦元 }\end{array}$ & & $\begin{array}{l}\text { 凅川芝浦海濱の道路を修治せしめらるるとて. 御側久 } \\
\text { 世大和守濱之監視にまかる.こは先年波濤のために崩 } \\
\text { れたるゆへな依の.依韓使來聘品川芝浦海濱道路修治 }\end{array}$ \\
\hline 7 & $\begin{array}{c}1657 \\
\text { 明暦3 }\end{array}$ & & 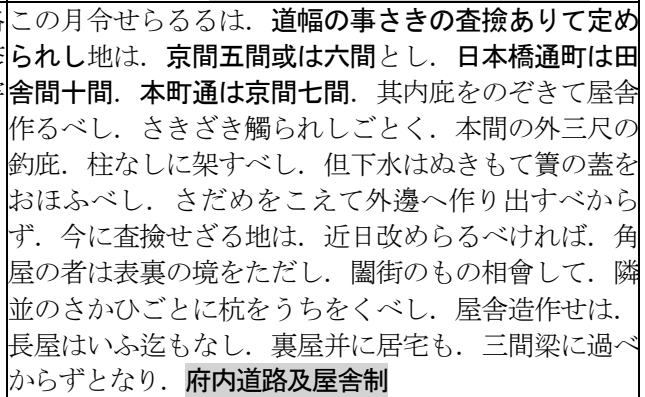 \\
\hline
\end{tabular}

とある、その他には，本節の e)で詳述する慶安 2（1649） 年（表-16 No.4），道路の表層に海砂や浅草砂を敷き詰 めるよう，補修の指示が出されていた，中山道は，他の 五街道に比べて山間部を通るため，維持管理に手間がか かっていたと推察される.

c) その他の補修に関する事項

その他の「道路」に関する補修は，寛文4（1664）年 の記述（表-17 No.11）をみると，

「けふ令せらるるは. こたび關東の國々巡視命ぜらるる により．往還の便を得べきため．道路．橋梁を修めし むべし.」

人々の往来を都合良くするために，関東の国々を見回り， 道路，橋梁を修理したという。

\section{d) 災害復旧に関する事項}

災害復旧に関わる事項として，地震 2 項目（表-16 No.2，表-17 No.13），火災 4 項目（表-16 No.5，No.7，表

表-17『徳川実紀』に記載された「補修」の項目（2/2）

\begin{tabular}{|c|c|c|c|}
\hline o. & $\begin{array}{l}\text { 西暦 } \\
\text { 和暦 }\end{array}$ & & $\begin{array}{c}\text { 記載事項 } \\
\text { (斜線部は『徳川実紀』に記載の脚注) }\end{array}$ \\
\hline 8 & 1660 & & $\begin{array}{l}\text { 市中一町のうち. 木戸の左右に手桶各三十. 片町は十 } \\
\text { 五出して水を貯べし. 梯は一町に六づつ. 片町三づつ } \\
\text { 設べし. 表一間半より四間半迄の家は手桶三づつ. } \\
\text { の内外心のままに設べし. 五間より九間半迄は五づ } \\
\text { つ. 十間より二十間までは十づつ前のごとく設置へ } \\
\text { し. 水道なき地は. 木戸際に水桶一を設置. 手桶. 梯 } \\
\text { は十月晦日を限としてつくりたて置べしとなり.消防制 }\end{array}$ \\
\hline 9 & \begin{tabular}{c|c|} 
寛文3 \\
\end{tabular} & 補修 & 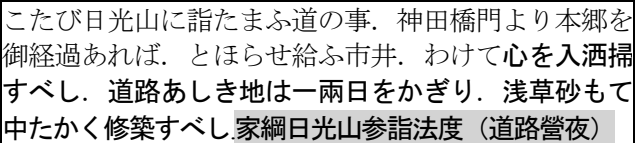 \\
\hline 10 & $\begin{array}{l}1664 \\
\text { 寛文4 }\end{array}$ & & $\begin{array}{l}\text { により。大番組 } \\
\text { 治并に扈從の事仰 } \\
\text { 修治 }\end{array}$ \\
\hline 11 & \begin{tabular}{c|}
1664 \\
寛文4
\end{tabular} & & 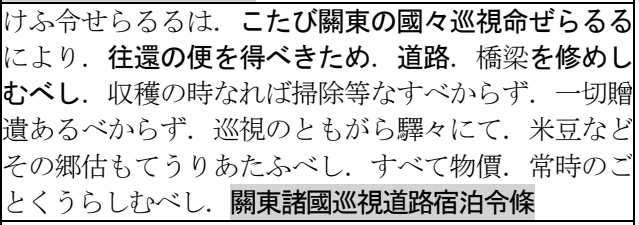 \\
\hline 12 & \begin{tabular}{|c|}
1696 \\
元禄 9
\end{tabular} & & 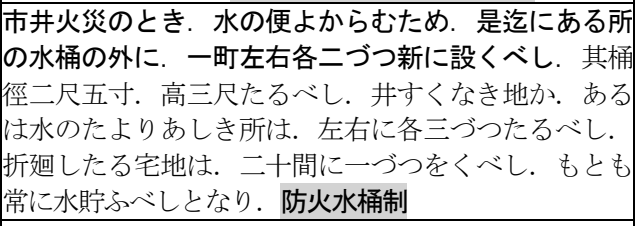 \\
\hline 13 & \begin{tabular}{l|l|}
1707 \\
宝永4
\end{tabular} & $\begin{array}{l}\text { 峟修 } \\
\text { 犗 }\end{array}$ & $\begin{array}{l}\text { より. 諸道堤防破損 } \\
\text { 河内守正岑. 少老稳 } \\
\text { 仿修理 }\end{array}$ \\
\hline 14 & \begin{tabular}{l|l|}
1722 \\
享保7
\end{tabular} & & 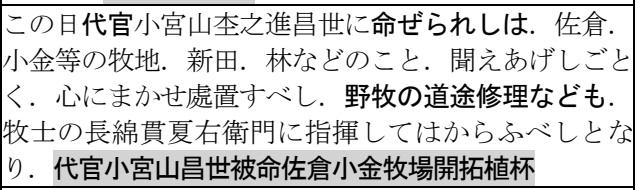 \\
\hline 15 & $\begin{array}{l}1783 \\
\text { 天明 } 3\end{array}$ & & 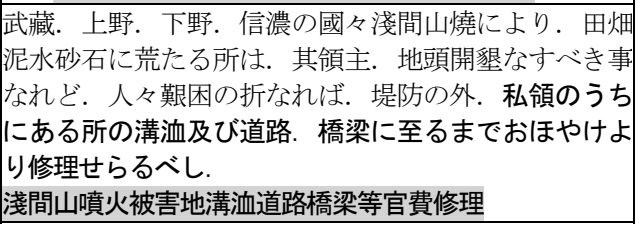 \\
\hline
\end{tabular}


-17 No.8, No.12），噴火 1 項目（表-17 No.15）が示され ていた.

寛永 10（1633）年には（表-16No.2）,

「今曉關東大地震す。こと更相州小田原一驛ことごとく 破潰し．民屋一宇ものこらず．泥水湧出．箱根山より 岩石くづれて落て. 行人これがためにうたれ. 死する もの多かりしとぞ．よて稲葉丹後守正勝に．速に道路 の修治を加ふべしと命ぜらる。」

関東で発生した大地震で箱根山から岩石が崩れ落ち，そ れによる道路の修築が命じられた。宝永 4（1707）年

（表-17 No.13）にも，宝永地震により破損した道路や堤 防の修理を速やかに行う必要があると示されていた.

江戸で火災が発生した場合に備え，等間隔に井戸の掘 削，水桶の設置が行われた（表-16 No.5，表-17 No.8， No.12）。さらに, 明暦 3 （1657）年の明暦の大火発生後 は，街路復員の変更（表-16No.8）が実施された.

天明 3 （1783）年に発生した浅間山大噴火では（表-16 No.8) ,

「私領のうちにある所の溝洫及び道路. 橋梁に至るまで おほやけより修理せらるべし.」

私領にある田畑の間を流れる溝や道路，橋梁であっても 江戸幕府が修理したとある，浅間山噴火による被害は， 大規模であったことが想像される.

\section{e) 浅草砂を用いた道路の補修}

道路の補修を行う際, 浅草砂を用いたという記述が,

17 世紀中頃にのみ存在した.『日本国語大辞典』38)には, 「浅草砂」と「浅草砂利」の項目が示されており，「浅 草砂」は,

「江戸初期，江戸浅草辺から採取した砂。」

そして，「浅草砂利」については，

「江戸初期，江戸で地突に用いた浅草産の砂利。」

とある.「浅草砂」の初出は，「4(2) 維持管理」に該 当した慶安元（1648）年（表-4No.10）の項目で,

「この月令せられしは．市井泥濘の道路は．浅草砂に海 砂まじへ，道途高低なく中高に築くべし．芥ならびに 雍埋せざるやう塵芥を除くべし．もしそむくものは曲 泥もて街道を築くべからず．下水の樋井に路傍の溝渠 事たるべしとなり.」

道路の断面形状をかまぼこ型にし，降雨時には排水を速 やかに行うことができる横断面に修築し，その際の材料 は「浅草砂」を用いよとの記述であった。この記述につ いて，『明治以前日本土木史』 ${ }^{39} に は ，$

「御府内備考巻之十七淺草之五に記する所によれば，萬 治三年（2320）に御城天守御普請用の砂利取場御用地 となりたる，「淺草田町一丁目之内西側凡百間之場所, 字砂利場と唱申候」といふ土地（浅草寺領），及び寛 文四年（2324）に其東側にても同様，「小石取場御用 被召上候」とある土地（淺草寺領）の一帯より，所請
山砂利の産出せしことは明にして，又「淺草寺北大門 通り観音院内東西の砂利場之内西砂利場之跡（中略） 並東砂利場云々」とある通り，砂利と小石とを同義に 解したる時代なれば，砂碩を「淺草砂」と特稱したる ことも別に怪しむに足らざるなり。されば之を以て路 面の敷砂利に關する初見とし，且路面を蒲鉾形に中高 に仕上ぐることは, 路面排水に留意したる路面固めと して, 幼稚なれども，具體なる技術上の存在といふべ きなり。（※引用部の数值は，皇紀を示す）」

万治 3（1660）年に続き，寛文 4（1664）年に江戸城の 普請で用いる採石場として，浅草が選出されていたとみ られる。『徳川実紀』における「浅草砂」の初出は, そ れより 12 年前の慶安元（1648）年であったことから， すでに道路に敷く砂あるいは砂利を採取できる状況にあ ったと考えられる.

翌年の慶安 2（1649）年（表-16 No.4）には,

「又市井に令せらるるは.こたび大納言殿日光御詣によ

り。御経過の道路は. みな廣さ一間半通りに海砂をし

き．兩脇にある家の前には浅草砂をしくべし（中略） 市街の兩端. 浅草砂少しづつ敷べし. もし路せばき所 はこの事に及ばずとなり。」

また，寛文3（1663）年（表-17No.9）の記述をみると， 「こたび日光山に詣たまふ道の事. 神田橋門より本郷を 御経過あれば. とほらせ給ふ市井. わけて心を入洒掃 すべし，道路あしき地は一兩日をかぎり。浅草砂もて 中たかく修築すべし.」

とある，道路状況が悪くなっている箇所には，浅草砂を 敷いて修築せよとの記述であった。このように，17世 紀中頃にのみ「浅草砂」を用いよとの指示が集中してお り, 上述した 3 ヶ所以外ではみられない状況にあった。

\section{6. 調査}

主として，「道路」の位置等を示した地図や絵図等を 作成した記述が 4 ヶ所で記載されていた。

\section{(1) 測地 - 作図}

17 世紀初頭の寛永 11（1634）年（表-18No.1）には, 「十五日留守居酒井紀伊守忠吉は. 目付黒川八左衛門盛 至并書工一人そへて. 伊豆海邊の山水道路の圖を作る ベしと仰付られかの地に赴く。これ御上洛によてな

り.」

伊豆浻岸部の自然地形に「道路」を加えた図を作成した. それから 12 年後の正保 3（1646）年（表-18 No.2）には, 「大番松田六郎左衛門定平. 飯河新右衛門直信. 府より 大坂迄の驛々道橋を巡察し。地圖を造るべしと仰付ら れ暇給ふ」 
表-18『徳川実紀』にみる「測地・作図」の項目

\begin{tabular}{|c|c|c|c|}
\hline No. & $\begin{array}{l}\text { 西暦 } \\
\text { 和暦 } \\
\end{array}$ & |項目 & $\begin{array}{c}\text { 記載事項 } \\
\text { （斜線部は『徳川実紀』に記載の脚注） }\end{array}$ \\
\hline 1 & $\begin{array}{l}1634 \\
\text { 寛永 } 11\end{array}$ & & $\begin{array}{l}\text { 留守居酒井紀伊守忠吉は. 目付黒川八左衛門盛至并 } \\
\text { 工一人そへて. 伊豆海邊の山水道路の圖を作るベし } \\
\text { 仰付られかの地に赴く.これ御上洛によてなり. }\end{array}$ \\
\hline 2 & \begin{tabular}{l|}
1646 \\
正保3
\end{tabular} & & $\begin{array}{l}\text { 大番松田六郎左衛門定平. 飯河新右衛門直信. 府よ } \\
\text { 大坂迄の驛々道橋を巡察し. 地圖を造るべしと仰付 } \\
\text { れ腵給ふ. 令製江戸大坂間驛路圖 }\end{array}$ \\
\hline 3 & $\begin{array}{l}658 \\
\text { 万治元 }\end{array}$ & & 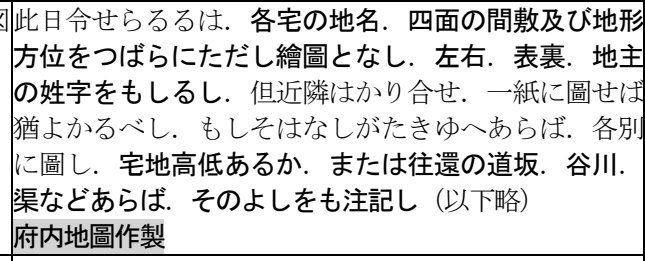 \\
\hline 4 & $\begin{array}{l}1709 \\
\text { 宝永6 }\end{array}$ & & 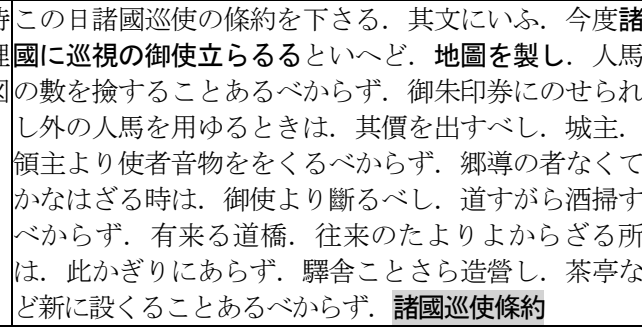 \\
\hline
\end{tabular}

江戸から大阪までの宿場, 道路, 橋梁を巡察したうえで, 地図が作成された。

万治元（1658）年（表-18No.3）では,

「此日令せらるるは．各宅の地名．四面の間敷及び地形 方位をつばらにただし繪圖となし．左右．表裏．地主 の姓字をもしるし，但近隣はかり合せ。一紙に圖せば 猶よかるべし。もしそはなしがたきゆへあらば。各別 に圖し，宅地高低あるか。または往還の道坂。谷川。

渠などあらば。そのよしをも注記し（以下略）」 各々の建築名称と地主の苗字等を付記，地形の高低差や 方位を調整し，道路，河川，水路などを書き込んだ江戸 の地図（絵図）を作成した。

\section{7. まとめ}

本研究では，江戸時代前中期における道路行政政策が どのように整備されてきたのかを一次史料である『徳川 実紀』を用いて整理し，その分類を試みた。『徳川実紀』 には，149 項目の「道路」に関する記述があり，そのな かで表-2「1．規則の制定」に該当するものが 120 項目 で，81.0\%が該当した。

江戸幕府の根幹となる距離を表す里数, 街道の起点設 定などの「規格」は，江戸時代前期に集中した.

「維持管理」について，「道路」は絶えず修理，掃除 を欠かさないようにし，道路環境を美しく保つよう，そ の制度が定められていた。また，「道路」や宿場を定期 的に巡回して傷んだところないか確認もされていた。こ れらは，『徳川実紀』の対象とした各時代に隔たりなく，
関連の記述があった。

江戸幕府における「職掌」のなかで，普請奉行は土木 を掌る職と考えられてきた。『徳川実紀』の享保4

（1719）年（表-7 No.13）の記述には，武家邸宅のこと は普請奉行が掌るとあり，建築にも関与していた。 しか し，『徳川実紀』で具体的な「道路」に関する記述とい えば，道路掃除を行っていた程度であった。普請奉行は 土木を掌る職であったが，本研究で対象とした江戸時代 前中期においては，実際に道路の造成や修築，整備に携 わった記述は存在しなかった。

江戸時代に任命されたほとんどの普請奉行は，必ずし も土木の専門的な知識を必要とした職掌ではなかったと 考えられる.この点については，江戸時代の社会基盤整 備事業について整理をしたうえで，当時の職掌について 迫っていきたい

「流通・交通政策」の項目では，悪天候時や夜間であ っても，荷物輸送に必要な馬や人夫を宿場に置くことが 求められた，その他にも，往来の妨げとなる道路上の牛 車や大八車の違法駐車をやめるように求める記述もあっ た.

表-2「2．道路施工」に分類されたのは 25 項目で，全 体の $16.8 \%$ 程度であった，なかでも，道路の新規造成に 関する記述は少なく，改修・補修工事の記述が多い状況 にあった。

「新規造成」は4件が該当し，そのうちの2件は築城に 伴う道路造成であり，現代でいう社会基盤としての「道 路」とは性格が異なる整備内容であった.

「改良工事」では中山道が険阻であったことから，一 部区間の縦断勾配を緩くしたり，北陸道では高波の被害 があった道路の付け替えを行ったりしていた。

「補修」では，地震，火災，噴火などの災害を受けた 際の復旧工事に関する記述が 7 項目でみられた．地震や 噴火などの自然災害を受けた場合，官費を用いた幕府直 轄の事業が実施されていた[2].

それ以外の事項としては，道路の表面に浅草砂を使用 せよとの命も 17 世紀中頃に 3 項目ではあったが記され ていた．江戸を中心に伸びていく諸街道や江戸府内の道 路における維持管理，道路環境の保持といった現在に繋 がる種々の規則等が整備されていた。

\section{8. 考察}

7 章で述べてきたように，研究対象とした江戸時代前 中期において，幕府が関与する道路は主として五街道と 脇街道等で，対象とした道路は限定的であったものの， 新規造成や改良工事，補修は数えられる程度の記述しか なく，ほとんど実施されていなかった。 なお，地方の事 
績についても同様で，改良工事や補修に関する記述にと どまっていたことを明らかにした ${ }^{[3]}$.

そして，交通および物流に関する記述が最も多く，江 戸を中心とした人の動きや荷物輸送に重きが置かれてい たと考えられる.

諸大名に義務づけた参勤交代など，幕藩体制を維持す るために実施していた交通政策のなかに「道路」に関す る種々の事項が位置づけられていたとみられる.

筆者らは, 1 章で示したように古代から中世にかけて 土を忌み嫌う「犯土」思想が影響して，「土木事業の空 白・停滞期」が存在していたことを明らかにしてきた

（図-1）．続く近世に入ると，食糧増産のために用水路 開削や新田開発などが行われるようになった。しかし， 本研究で対象とした江戸時代前中期の「道路」に限って いえば，補修などの維持管理は行われていたものの，幕 府直轄による新規の道路造成に代表される土木工事は積 極的に行われていなかった．ちなみに，幕府直轄の事業 としては, 宝永地震からの災害復旧時に実施された程度 であった ${ }^{[2]}$.

先述した「犯土」思想が, 本研究の対象とした江戸時 代前中期に影響を及ぼしていたかは不明であったものの, 幕府はその体制を維持するために江戸へ攻め入れられる ことを防ぐ必要があった，そのために，江戸幕府は交通 の便を良くするための土木工事を抑えていたと推察され る状況にあったことを示した。

\section{補注}

[1] 本研究は，あくまでも一次史料である『徳川実紀』から， 「道路」に関する記述を整理していくことで，江戸幕府 下における社会基盤整備の実態を網羅的に明らかにして いくことが目的である，そのため，原則として個々の事 例については，他の文献を用いた検討は行っていない． そして，5 章で明らかにした「道路」の「新規造成」や 「改良工事」「補修」の具体的な事例は，史実のみの記 載にとどまっていた。 それ故, 『徳川実紀』には事業毎 の整備において，どれだけの予算が必要であったかには 言及されていなかった，手伝い普請等に代表される幕府 と地方の財政負担に関する記述もその記載がなかった.

[2]研究対象とした『德川実紀』では，将軍や老中といった 江戸幕府の重要な職位を持つ人物名には，その職名が付 記されることはなかった。1633（寛永 10）年の関東大地 震（表-16 No.2）で道路の修築にあたった稲葉正勝, 宝永 4 （1707）年発生の宝永地震（表-17 No.13）の復旧にあた った井上正岑は老中職であった，老中は，国史大辞典編 集委員会：『国史大辞典 第 14 巻』, 吉川弘文館, p.754, 1993 によれば, 「江戸幕府の常置の最高職で, 将軍に直 属して幕政全体を統括した（以下略）」。そして，宝永 地震の項目で名前が挙がっていたもう一人の稻垣重富は, 若年寄（少老ともいう）であり，前掲，p.850 をみると， 「江戸幕府で老中につぐ要職. 将軍に直属し, 老中支配 以外の諸役人および旗本を統括した，定員は三〜五名 （以下略）.」の職にあった。このように, 幕府の重職 が震災からの復旧作業に携わったことから，その被害は 相当のものであったと推測される.

一次史料である『徳川実紀』に掲載されたすべての記述 を研究対象とした，そのなかから社会基盤整備に関する 事項を抜き出すことで，江戸幕府における道路行政政策 を明らかにした，本研究の範疇からは外れるが，江戸時 代前中期において，果たして「2. 道路施工」に該当する 項目は本当に少なかったのか, 各時代の土木史に関する 事項を網羅して掲載された参考文献 5), pp.902-969 および 参考文献 6), pp.78-105 を用いて明確にした. その結果, 『徳川実紀』で掲載されておらず，上述の先行研究にの み掲載されている「2. 道路施工」に該当する項目は，下 表に示したわずか 6 項目だけであった。「2(1)新規造成」 に該当する項目は，5(1)で示した 4 項目が掲載されていた が, 先行研究には, その項目は掲載されていなかった。

「2(2)改良工事」に該当寸る項目は，6 事業が掲載されて いたのに対して, 先行研究には表-19の 2 事業, 3 項目が 記載されていた. 元文元 (1736) 年から 3 年にわたって, 1(3)d)でも示した木食僧正彈が幕府の許可を請け, 東海道 中京都・大津間の日岡峠の急坂，三百間（約 $545.4 \mathrm{~m} ）$ を 平均勾配 $1 / 20$ に改修し, 牛車道には白川石を敷き詰めた たことが掲載されていた（表-19No.3）。宝暦8（1758）年 には，僧鞭牛（生没年：1710 1782）が，岩手県盛岡市と 同県宮古市を結ぶ宮古街道（別称：閉伊街道）の $393 \mathrm{~km}$ を 30 年間にわたり改修していた（表-19 No.2，No.4）。い ずれの事例も，既存道路の改修で新規造成ではなかった。 「2(3)補修 (災害復旧を含む) 」該当する項目は 3 項目 でみられた，その記述は，街道沿いに植えられた並木の 手入れなどが示されていた（表-19 No.5，No.6）。やはり， 先行研究をみても, 本研究で対象とした江戸時代前中期 における具体の施工例は少なかった，その一因として考 えられるのは，江戸幕府が道路を新規に造成することで 交通の便を良くして，江戸府内と諸国が近づくことを嫌 ったと考えられる. 参考文献 5)，p.956 にも「幕府諸大名 の仮亂を企つるを憂へ，軍事的及び政治的の顧慮より， 驛遞の如き四方の消息を速報するに必要なる人事的制度 の設備にのみ重きを置き，土地に固着したる施設には， 故意に交通を阻害したる類のものもありたり。」とある。 幕府直轄による道路の新規造成は積極的に行われず，災 害復旧のための道路修築が害施された程度であったもの の, 諸大名の参勤交代を義務付けており, 道路の維持管 理および補修等は街道沿いで多少実施されていたと考え られる。一方で, 先行研究として用いた参考文献 5)，6は， 『徳川実紀』と同時代の一次史料をすべて網羅して列举 
表-19『明治以前日本土木史』および『日本土木史総合 年表』にみる「2. 道路施工」に該当する項目

\begin{tabular}{|c|c|c|c|}
\hline & \begin{tabular}{l|} 
西暦 \\
和暦
\end{tabular} & 項目 & $\begin{array}{c}\text { 記載事項 } \\
\text { （斜線部は『徳川実紀』に記載の脚注） }\end{array}$ \\
\hline 1 & \begin{tabular}{c|c}
1628 \\
寛永 5
\end{tabular} & & 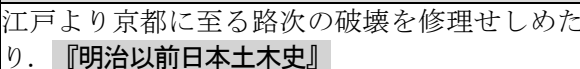 \\
\hline 2 & \begin{tabular}{|l|l|} 
寛永1841 \\
\end{tabular} & & $\begin{array}{l}\text { 南部藩, 閉伊街道を全面改修, 42町を1里として堟 } \\
\text { を築造. 『日本土木史総合年表』 }\end{array}$ \\
\hline 3 & $\begin{array}{ll}1736 \\
\text { 元文元 }\end{array}$ & & 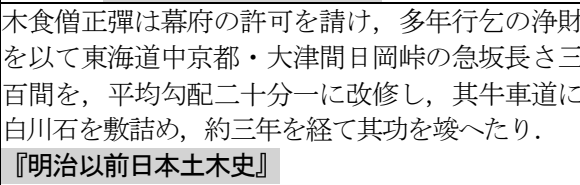 \\
\hline 4 & $\begin{array}{l}1758 \\
\text { 宝暦8 }\end{array}$ & & $\begin{array}{l}\text { 僧鞭牛（1710～1782）が指導し，岩手県の閉伊街道 } \\
\text { (現，国道108号線）393kmを30年間にわたり築造 } \\
\text { 『日本土木史総合年表』 }\end{array}$ \\
\hline$\overline{5}$ & \begin{tabular}{|c|}
1762 \\
宝暦12
\end{tabular} & & 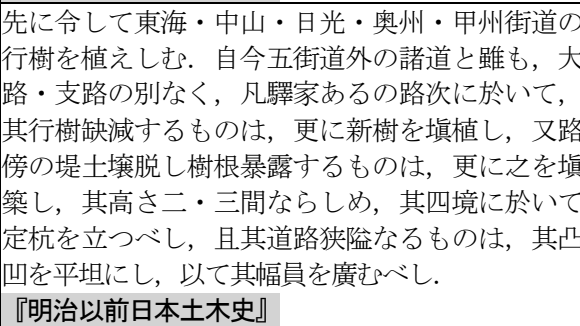 \\
\hline & \begin{tabular}{|l|l|}
1763 \\
宝暦13 \\
\end{tabular} & & $\begin{array}{l}\text { 幕府，東海道・日光街道などの並木植栽と手入れ } \\
\text { を命令. 『日本土木史総合年表』 }\end{array}$ \\
\hline
\end{tabular}

されているわけではない，今後は，各藩の歴史書を研究 対象とし，研究範囲を広げていく必要がある.

\section{参考文献}

1) 西山孝樹, 知野泰明：紀の川上・中流域における近世 中期以前の灌溉水利の変遷に関する研究，土木学会論 文集 D2（土木史），Vol. 68, No. 1, pp. 11-21, 2012.

2) 西山孝樹, 藤田龍之：わが国の「土木事業の空白期」 における土木と関係する官職，土木学会論文集 D2 （土木史）, Vol. 70, No. 1, pp. 9-19, 2014.

3) 武部健一：道路の日本史一古代駅路から高速道路一, 中央公論新社, $253 \mathrm{p} ., 2015$.

4) 石井進, 五味文彦, 笹山晴生, 高埜利彦：詳説日本史 改訂版, p. 58, 山川出版社, 2008.

5) 土木学会編 : 明治以前日本土木史, 1759p., 岩波書店, 1936.

6) 三浦基弘, 岡本義喬：日本土木史総合年表, 503p., 東京 堂出版, 2004.

7) 高橋裕：現代日本土木史 第二版, 244p, 彰国社, 2007.
8) 丸山雍成：日本近世交通史の研究，p．1，吉川弘文館， 1989.

9）武部健一：道のはなし I, pp. 78-79, 技報堂出版, 1992.

10) 前掲 9), p. 79.

11）前掲 8), p. 2.

12）渡辺和敏：近世交通制度の研究，p. 8, 吉川弘文館, 1991.

13）前掲 8), p. 18.

14) 前掲 8), p. 2.

15）巟玉幸多：日本交通史, p. 199, 吉川弘文館, 1992.

16）巟玉幸多：近世交通史の研究, p. 5, 筑摩書房, 1986.

17) 前掲 9), p. 89

18）前掲 15), pp. 205-206.

19) 前掲 8), pp. 22-23.

20）前掲 8), p. 12.

21）前掲 12), p. 11.

22）前掲 16), p. 5.

23）前掲 15), p. 218.

24）大島延次郎：日本交通史概論，pp. 144-150, 吉川弘文 館, 1964.

25) 前掲 9), p. 83.

26）前掲 15), p. 214.

27) 前掲 9), p. 87.

28) 前掲 15), pp. 214-215.

29）前掲 15), p. 218.

30) 国史大辞典編集委員会: 国史大辞典 第 10 巻, pp. 289-290, 吉川弘文館, 1989.

31) 黒板勝美: 新訂増補版 徳川實紀〈第 1 篇〉（国史 大系）～徳川實紀〈第 10 篇〉（国史大系），吉川弘 文館, 1990-1991.

32) 堀内信 : 南紀徳川史, p. 5, 清文堂出版, 1989.

33）社団法人土木学会：土木用語大辞典,pp. 1100-1101, 技報堂出版, 2005 .

34) 川口謙二：江戸時代奉行職事典 東京美術選書 (33), pp. 154-155, 東京美術, 1983.

35）豊田武，児玉幸多：体系日本史叢書 24 交通史，pp. 122-135, 山川出版社, 1970.

36) 日本国語大辞典第二版編集委員会, 小学館国語辞典編 集部：日本国語大辞典 第 1 巻, p. 1390, 小学館, 2000.

37) 松村明, 小学館大辞泉編集部 : 大辞泉, p. 1213, 小学館, 2012.

38）前掲 36), p. 265.

39）前掲 5), p.956.

(2018. 7.17 受付) 


\section{THE ROAD ADMINISTRATION SYSTEM OF CASE STUDY FROM THE TOKUGAWA JIKKI IN THE EARLY AND MIDDLE EDO SHOGUNATE}

\section{Takaki NISHIYAMA, Tatsushi FUJITA and Koichi AMANO}

Infrastructure projects implemented in Japan in the Edo shogunate are said to have built the foundation for the country's present. However, there has not been an exhaustive study based on primary historical sources to clarify how these projects were implemented under the Edo Shogunate.

The present research focuses on the road administration system implemented during the early and middle Edo Shogunate by referring to Tokugawa Jikki, official records compiled by the Edo Shogunate. The study revealed 149 items related to roads. Categorization of these items found that the highest number of 120 items touched on the formulation of rules to determine policies on distribution and transport, as well as maintenance and management of roads. Meanwhile, only 25 items discussed the topic of road construction, namely, the building and repairing of roads.

During the early and middle Edo Shogunate that was studied, roads were maintained and managed but not actively constructed under the direct control of the Shogunate. This indicates that the Edo Shogunate refrained from implementing civil engineering projects for improving transportation systems, ostensibly due to the need to prevent attacks upon the Edo Area and maintain the Bakuhan system. 